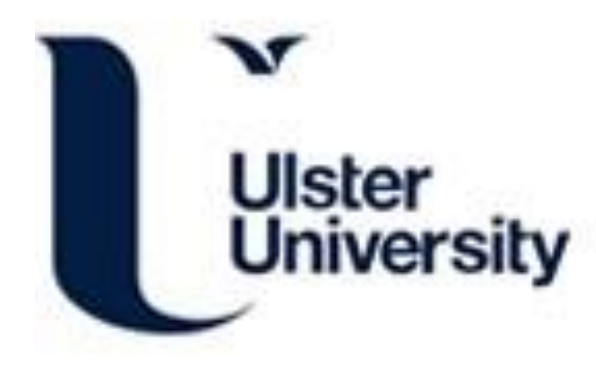

\title{
Electrochemically assisted photocatalysis for the simultaneous degradation of organic micro-contaminants and inactivation of microorganisms in water
}

Salmerón, I., Sharma, P. K., Polo-López, M. I., Tolosana, A., McMichael, S., Oller, I., Byrne, J. A., \& FernándezIbáñez, P. (2021). Electrochemically assisted photocatalysis for the simultaneous degradation of organic microcontaminants and inactivation of microorganisms in water. Process Safety and Environmental Protection, 147, 488-496. https://doi.org/10.1016/j.psep.2020.09.060

Link to publication record in Ulster University Research Portal

\section{Published in:}

Process Safety and Environmental Protection

Publication Status:

Published (in print/issue): 31/03/2021

DOI:

10.1016/j.psep.2020.09.060

\section{Document Version}

Author Accepted version

\section{General rights}

Copyright for the publications made accessible via Ulster University's Research Portal is retained by the author(s) and / or other copyright owners and it is a condition of accessing these publications that users recognise and abide by the legal requirements associated with these rights.

\section{Take down policy}

The Research Portal is Ulster University's institutional repository that provides access to Ulster's research outputs. Every effort has been made to ensure that content in the Research Portal does not infringe any person's rights, or applicable UK laws. If you discover content in the Research Portal that you believe breaches copyright or violates any law, please contact pure-support@ulster.ac.uk. 
Title: Electrochemically Assisted Photocatalysis for the Simultaneous Degradation of Organic Micro-Contaminants and Inactivation of Microorganisms in Water

Authors: I. Salmerón ${ }^{\mathrm{a}}$, P. K. Sharma ${ }^{\mathrm{b}}$, M.I. Polo-López ${ }^{\mathrm{a}}$, A. Tolosana ${ }^{\mathrm{b}}$, S. McMichael ${ }^{\mathrm{b}}$, I. Oller $^{\mathrm{a}}$, J.A. Byrne ${ }^{\mathrm{b}}$, P. Fernández-Ibañez ${ }^{\mathrm{b}^{*}}$

aPlataforma Solar de Almería-CIEMAT. Ctra Senés km 4, 04200 Tabernas (Almería), Spain.

${ }^{b}$ Nanotechnology and Integrated BioEngineering Centre, School of Engineering, Ulster University, Northern Ireland, BT37 0QB, United Kingdom

* Corresponding author:

Pilar Fernandez: p.fernandez@ulster.ac.uk 


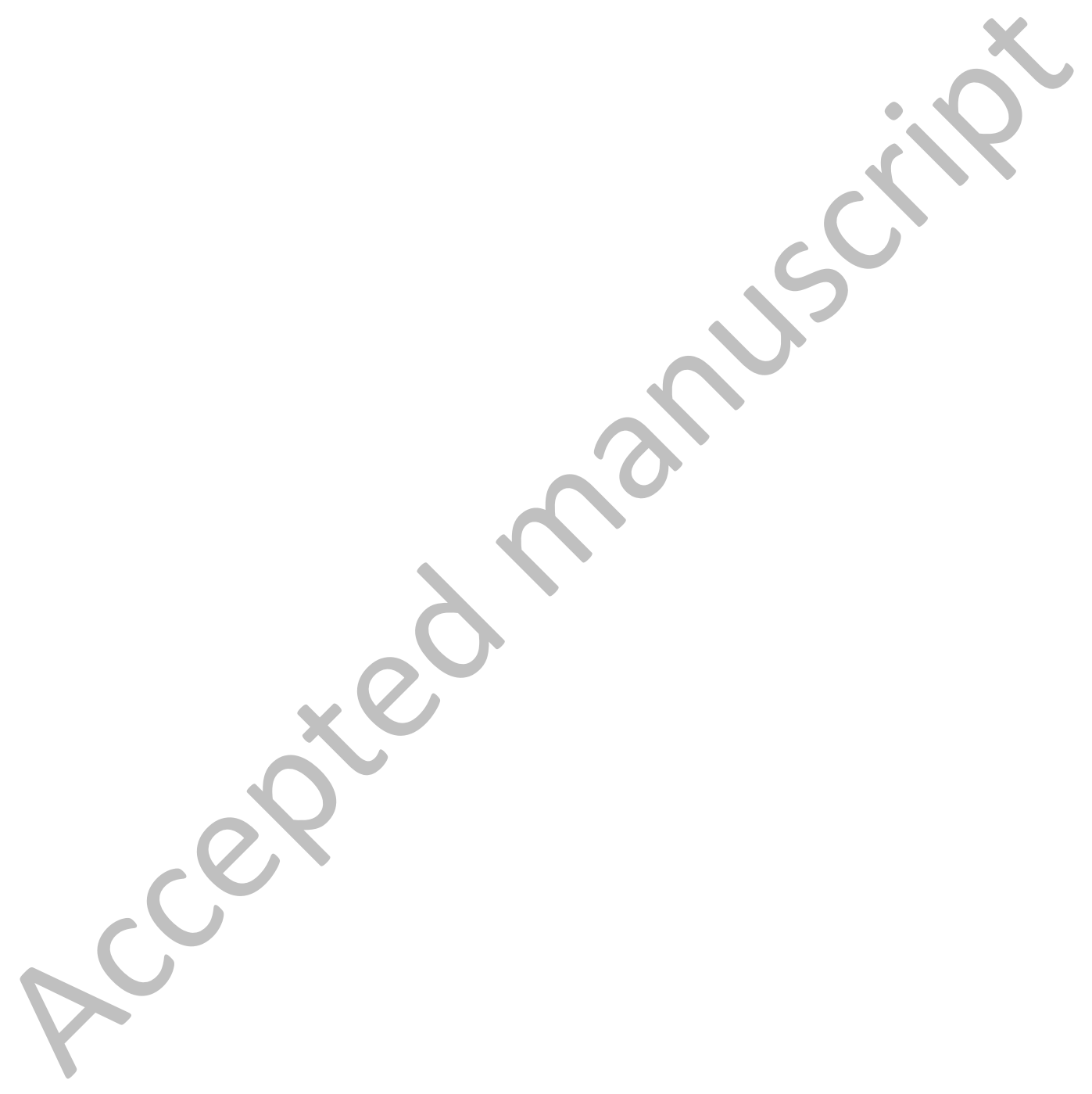




\section{ABSTRACT}

This study presents the assessment of the performance of a photoelectrochemical reactor for the simultaneous degradation of organic microcontaminants (OMCs) and inactivation of bacteria in real surface water. Target OMCs were terbutryn, clorfenvinphos and diclofenac (500 $\mu \mathrm{g} \mathrm{L}-1$ each), and E. coli $\mathrm{K} 12\left(10^{6} \mathrm{CFU} \mathrm{mL}^{-1}\right)$ was used as the model microorganism. The reactor utilised a photoanode consisting of two Ti mesh electrodes anodised to give aligned self-assembled $\mathrm{TiO}_{2}$ nanotubes on the surface. Two cathode materials were investigated i.e. Pt and carbon felt. Higher E. coli inactivation rates were observed with electrochemically assisted photocatalysis (EAP) with a 2-Log Reduction Value (LRV) for Pt CE and 2.7-LRV in $2 \mathrm{~h}$ for carbon felt cathode, as compared to only a $0.8 \mathrm{LRV}$ for photocatalysis (open circuit). For the simultaneous degradation of OMCs and inactivation of bacteria a 4.5-LRV was achieved in $90 \mathrm{~min}$ with applied potential and a carbon felt cathode. Similar degradation kinetics were observed for the OMC for both electrochemically assisted photocatalysis and photocatalysis (open circuit) with ca $70 \%$ of the removal of the total OMCs in 60 min. Hydroxyl radical, $\mathrm{H}_{2} \mathrm{O}_{2}$ and chlorine generation were also evaluated to elucidate the mechanisms of degradation and disinfection. This work suggests that electrochemically assisted photocatalysis is more efficient than photocatalysis alone for the combined removal of OMCs and disinfection of water.

Keywords: Carbon-felt cathode, Escherichia coli, organic microcontaminants, photoelectrocatalysis, $\mathrm{TiO}_{2}$ nanotubes photoanode, water purification. 


\section{Introduction}

The increase of the pharmaceutical and agricultural industry during the last decades has led to the appearance of new organic substances into the environment. These compounds are commonly present at very low concentrations, from $n \mathrm{~L}^{-1}$ to $\mu \mathrm{g} \mathrm{L}^{-1}$, however they are highly toxic or nonbiodegradable and their effects into the ecosystems and humans are still unknown. Their recalcitrant character makes them unable to be removed by biological treatments thus in wastewater treatment plants (WWTP) without a proper tertiary treatment they are directly discharged into water bodies. Furthermore, wastewater will contain pathogenic microorganisms which should be inactivated before discharge to certain catchments or before reuse for irrigation. In this context Advanced Oxidation Processes, able to generate a highly oxidative species, appear as a useful tool for the simultaneous removal of organic microcontaminants (OMCs) and bacteria.

Titanium dioxide $\left(\mathrm{TiO}_{2}\right)$ is a semiconductor photocatalyst widely investigated for the degradation of pollutants and inactivation of microorganisms.; however, $\mathrm{TiO}_{2}$ photocatalysis requires UV excitation, and typically displays low quantum efficiencies due to fast charge carrier recombination. Where the $\mathrm{TiO}_{2}$ is immobilised on an electrically conducting support, the application of an external electrical bias improves the separation of the photogenerated charge carriers, and thus improves the overall efficiency (Byrne et al., 2002). This process is normally referred to as electrochemically assisted photocatalysis (EAP), photoelectrocatalysis or sometimes, photoelectrolysis. The immobilization or formation of the catalyst on a support can decrease the effective surface area available for reaction, and may result in mass transfer limitations in the reactor (Leng et al., 2006; Pablos et al., 2017a). However, in EAP, mass transport might be improved due to the electromigration of negatively charged bacteria to a positively biased photoanode (Pablos et al., 2017a).

With EAP, oxidation of water at the semiconductor electrode (photoanode) gives hydroxyl radicals and reduction of molecular oxygen at the cathode can generate superoxide radical anion, hydrogen peroxide, and hydroxyl radicals. In natural water matrices containing dissolved ions, the EAP leads to the generation of other species including active chlorine species (ACS), $\mathrm{HClO}$ $\left(E^{0}=1.49 \mathrm{~V} / \mathrm{SHE}\right)$ and $\mathrm{ClO}^{-} \quad\left(E^{0}=0.89 \mathrm{~V} / \mathrm{SHE}\right)$ (Moreira et al., 2017), which are widely recognized as key oxidants in electrolytic water treatment. In a photoelectrochemical cell (PEC), the sites for oxidation and reduction are spatially separated avoiding surface recombination reactions, and photogenerated charge carriers are separated under the influence of the electric field, decreasing the rate of bulk recombination. 
Generally, Pt has been used as counter electrode because its good chemical resistance to corrosion even in strongly aggressive media (Panizza, 2010) and low overpotential for reduction reactions such as $\mathrm{H}_{2}$ evolution. However, carbon-based electrodes have been extensively studied as cathodes (Cotillas et al., 2015; Le et al., 2017) due to their selective reduction of molecular oxygen to hydrogen peroxide (Panizza, 2010). The use of carbon cathodes is widespread in other electrooxidative processes for the in situ generation of Fenton reagent, such as electro-Fenton (Le et al., 2017) or solar photoelectro-Fenton. Most published research does not specifically consider the nature of the counter electrode in EAP, however, Xie and $\mathrm{Li} \mathrm{(2006)} \mathrm{reported} \mathrm{a} \mathrm{significant} \mathrm{increase}$ in the degradation of orange-G dye from $3.4 \%$ with a Pt cathode to $25.1 \%$ using reticulated vitreous carbon (RVC).

Previous research has reported that EAP using titanium dioxide nanotube $\left(\mathrm{TiO}_{2}-\mathrm{NTs}\right)$ electrodes can achieve high inactivation rates for bacteria (Baram et al., 2009; Pablos et al., 2017b), even in seconds (Liu et al., 2013) depending on the reactor configuration, electrical potential applied, and the electrolyte solution. For degradation of organic micropollutants, $\mathrm{TiO}_{2}-\mathrm{NTs} \mathrm{PEC}$ have been applied for contaminants removal such as diclofenac (Cheng et al., 2016), pentachlorophenol (Quan et al., 2007), or even aromatic amines (Cardoso et al., 2010). However, the use of these systems for real waters with the aim of simultaneous disinfection and elimination of OMCs, in a realistic range of $\mu \mathrm{g} \mathrm{L}^{-1}$, has not been reported.

To our knowledge, there are no studies published on simultaneous photoelectrocatalytic degradation of a mixture of organic microcontaminants at initial concentrations that mirror the environmental systems, and pathogenic bacteria in water using a real water matrix. For this purpose, the electrochemically assisted photocatalytic process was carried out in real surface water without the addition of a supporting electrolyte to assess the actual application and suitability of the process. To enhance the PEC treatment, different cathodes (Pt and carbon felt cathode) were used and it was observed that the carbon felt cathode improved the inactivation of bacteria. Furthermore, to deepen into the understanding of the process improvement, scavengers were used to determine the role of the main ROS. The goal of this study is to compare electrochemically assisted photocatalysis using a $\mathrm{PEC}$ reactor with a $\mathrm{TiO}_{2}-\mathrm{NT}$ photoanode with either a carbon felt or Pt cathode for the simultaneous degradation of OMCs and inactivation of bacteria. In this work terbutryn (TBT), chlorfenvinphos (CVP), and diclofenac (DCF), were selected as OMCs and E. coli $\mathrm{K} 12$ (at $10^{6} \mathrm{CFU} \mathrm{mL} \mathrm{mL}^{-1}$ ) was used as model microorganism. Natural (non-autoclaved or filtered) surface water was used for all experiments.

\section{Materials and methods}




\subsection{Water matrix characterization}

The water matrix used in this study was surface water. It was collected from a natural stream in Whiteabbey (Newtownabbey, UK). The characterization of this water matrix was done using a pH meter (multi720, WTW, Germany), conductivity meter (GLP31, CRISON, Spain), and turbidimeter (Model 2100N, Hach, USA). Ionic composition was measured using an ion chromatograph (IC) (Model 850, Metrohm, Switzerland). Dissolved organic carbon (DOC) was measured with a TOC analyser (Shimadzu TOC 5000A, Japan). Main characteristics of the water are $\mathrm{pH} 7.35$, electric conductivity of $697 \mu \mathrm{S} \mathrm{cm}^{-1}, 0.1 \mathrm{NTU}$ of turbidity, $6.9 \mathrm{mg} \mathrm{L}^{-1}$ of DOC and $18.4 \mathrm{mg} \mathrm{L}^{-1}$ of chloride. The detailed characterization is shown in Table SI-1.

\subsection{Bacterial enumeration and quantification}

E. coli K12 was obtained from the Spanish Culture Collection (CECT 4624). Fresh liquid cultures were prepared in Tryptone Soya Broth CM0129 (OXOID) and incubated during $20 \mathrm{~h}$ at $37{ }^{\circ} \mathrm{C}$

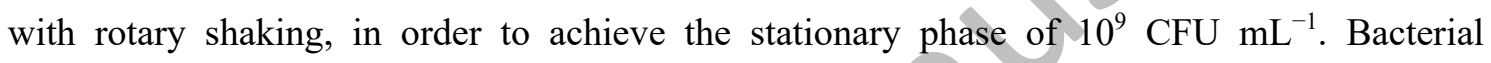
suspensions were diluted in the reactor to reach an initial concentration of $10^{6} \mathrm{CFU} \mathrm{mL}^{-1}$. The bacteria stock solution added to the water sample a DOC concentration of $6.7 \mathrm{mg} \mathrm{L}^{-1}$. All samples were enumerated using the standard plate counting method with Tryptone Soya Agar CM0131 (OXOID). Six $20 \mu \mathrm{L}$ drops of each dilution were plated. Colonies were counted after incubation at $37^{\circ} \mathrm{C}$ for $24 \mathrm{~h}$. The limit of detection (DL) was $9 \mathrm{CFU} \mathrm{mL}{ }^{-1}$.

For hole-acceptor experiments bacterial suspensions were harvested by centrifugation at 3000 rpm for 10 min. Then, the pellet was re-suspended in Phosphate Buffer Saline (PBS) solution and diluted directly into the sample to reach the initial concentration of $10^{6} \mathrm{CFU} \mathrm{mL}^{-1}$. Water samples taken during the experiments were enumerated using the standard plate counting method with ChromoCult ${ }^{\circledR C o l i f o r m ~ A g a r ~(M e r c k ~ K G a A, ~ D a r m s t a d t, ~ G e r m a n y) . ~ 10-f o l d ~ d i l u t i o n s ~ o f ~ w a t e r ~}$ samples were done in PBS, and volumes ranged between 50-500 $\mu \mathrm{L}$ were spread onto Petri-dishes surface. Colonies were counted after an incubation period of $24 \mathrm{~h}$ at $37^{\circ} \mathrm{C}$. Detection limit of this procedure was $2 \mathrm{CFU} \mathrm{mL}^{-1}$.

\subsection{Organic Microcontaminant Analysis}

TBT, CVP, and DCF were used as a representative mixture of OMCs since they cover a wide spectrum of commonly found chemical anthropogenic contamination in surface waters (herbicide, pesticide and drugs respectively). The OMCs used were analytical grade, purchased from SigmaAldrich. Stock solutions containing the three OMCs at $2.5 \mathrm{~g} \mathrm{~L}^{-1} / \mathrm{OMCs}$ were prepared in methanol (organic matrix to dissolve the $\mathrm{OMCs}$ ) and stored at $4^{\circ} \mathrm{C}$. stock solution $(38 \mu \mathrm{L}$ ) was diluted in the sample to reach an initial concentration of $500 \mu \mathrm{g} \mathrm{L}-1 / \mathrm{OMCs}$. The dilution of OMCs added 60 
mg L $\mathrm{L}^{-1}$ of extra DOC concentration to the water matrix. The OMC concentration was monitored by high performance liquid chromatography using a HPLC/UV Agilent Technologies Series 1100, equipped with an analytical column Luna C18 (4.6 mm x $150 \mathrm{~mm}, 3 \mu \mathrm{m})$ from Phenomenex. Injection volume was $100 \mu \mathrm{L}$. The three OMCs were simultaneously detected using a gradient method, from 90/10 (v/v) of formic acid (25 mM)/acetonitrile (ACN) to 100\% ACN after $14 \mathrm{~min}$

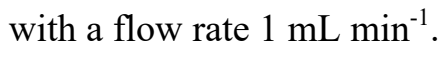

For HPLC measurements, samples were prepared mixing $900 \mu \mathrm{L}$ of sample and $100 \mu \mathrm{L}$ of ACN that were filtered through a Millipore Millex-GN $0.20 \mu \mathrm{m}$ nylon membrane filter. Then, the solution was transferred into HPLC vials, put in the HPLC and results analysed. Quantification of each OMC was done according to a standard curve previously prepared in the range of 10 to $1000 \mu \mathrm{g} \mathrm{L}^{-1}$. Retention time, limit of quantification (LOQ), limit of detection (LOD), and maximum absorption for each OMCs are shown in Table SI-2.

\subsection{Electrode preparation and characterization}

The $\mathrm{TiO}_{2}$-NT photoanodes were fabricated by electrochemical anodization of titanium mesh (Sigma-Aldrich) using the method described elsewhere (Shin and Lee, 2008). Briefly, titanium mesh $\left(75 \times 95 \mathrm{~mm}^{2}\right)$ were sonicated and washed in 5\% Decon90 detergent, distilled water and ethanol, sequentially. Electrochemical cell for anodization consisted of Pt coated Ti mesh cathode and titanium mesh as anode on each side of cathode, in a polypropylene beaker. The anodization process was repeated on the opposite side of the Ti mesh to have uniform nanotubes growth on both sides of the Ti mesh. The electrolyte solution was prepared by mixing $\mathrm{NH}_{4} \mathrm{~F}(0.3 \mathrm{wt} \%)$ in distilled water (3.0 vol\%) and ethylene glycol ( $97 \mathrm{vol} \%)$. The anodization was performed at $30 \mathrm{~V}$ for $3 \mathrm{~h}$ using a PLH120 Power Supply. After anodization, the foils were rinsed multiple times in distilled water and then annealed at $500^{\circ} \mathrm{C}$ in air for $20 \mathrm{~h}\left(\operatorname{ramp} 2{ }^{\circ} \mathrm{C} \mathrm{min}^{-1}\right.$ up and $1{ }^{\circ} \mathrm{C} \mathrm{min}^{-1}$ down $)$ in a Lenton AWF 12/5 Chamber Furnace.

The growth, coverage and dimensions of the $\mathrm{TiO}_{2}$-NTs were examined using scanning electron microscopy (SEM) at $10 \mathrm{kV}$ (Hitachi SU5000 FESEM). Energy dispersive X-ray analysis (EDX) was performed using Oxford Instruments EDX coupled with FESEM system.

\subsection{Photoelectrochemical cell configuration}

The total volume of the $\mathrm{PEC}$ reactor was $190 \mathrm{~mL}$, which was irradiated through a quartz window (Figure 1a). $\mathrm{TiO}_{2}$-NTs and platinized Ti mesh (Ti-Pt) mesh (Sigma-Aldrich) or carbon felt (Sigracet GDL 28 BC from Ion Power) were used as photoanode and cathodes for the different experiments, respectively. Electrode dimensions were $7.5 \mathrm{~cm}$ x $9.5 \mathrm{~cm}$, with a total surface area 
of $71.25 \mathrm{~cm}^{2}$ each. The electrodes were assembled following an anode-anode-cathode configuration in order to maximise the absorption of irradiated photons. The nanotubes were grown on $\mathrm{Ti}$ mesh that allowed $50 \%$ of the light to pass through its faces (experimentally determined). The misaligned mesh electrodes combination allowed only $25 \%$ of the light to pass through, so at least $75 \%$ of the direct photons interacted with the photoanodes. The reactor was operated in batch mode and electrodes were biased with a PLH120 Power Supply.

An air-blower was connected to the reactor with a flow rate of $0.36 \mathrm{~mL} \mathrm{~min}{ }^{-1}$ to avoid the depletion of dissolved oxygen during the photocatalytic process and simultaneously kept the solution stirred. Two 9W UVA black light lamps were placed in front of the Ti-mesh side of the PEC (Phillips, Actinic BL PL-S 9W/10/2P; 370 nm-peak wavelength). The irradiation profile of the lamps (Fig SI-1) was determined by the use of a GEMINI 180 scanning monocromator from HORIBA, measuring at different distances of the source aiming to achieve an incident irradiance of $50 \mathrm{~W} \mathrm{~m}^{-2}$ in the UVA, equivalent to high intensity solar UV with Air Mass of 1.5 (ASTM E490-00). A scheme of the complete system is shown in Figure 1b

\section{FIGURE 1}

\subsection{Photoelectrochemical experiments}

The reactor operational potential was determined according to the minimum potential at which maximum photocurrent (plateau) is reached (see section 3.3). For this purpose, several potentials were applied to the cell, increasing the interval by $0.1 \mathrm{~V}$ each time, measuring the current response in dark conditions and under irradiation for each applied potential. The photocurrent is calculated thought the difference between the current response under radiation and in dark. Current densities and applied potentials were measured using LAP MAS830B multimeter.

For OMCs and bacterial removal experiments the reactor was filled with surface water in natural conditions (without any pre-treatment or addition of reagents), at $\mathrm{pH} 7.4$ and air sparged. After a few minutes the target contaminant was added, whether it was the microorganism, the OMCs, or both, leaving to equilibrate for $10 \mathrm{~min}$. An initial sample $\mathrm{t}=0$ was taken and the reactor was biased and exposed to irradiation. The samples were taken at $5 \mathrm{~min}$ interval till $20 \mathrm{~min}$, every $15 \mathrm{~min}$ till $60 \mathrm{~min}$ and then every $30 \mathrm{~min}$ until the end of the. Before and after carrying out each experiment, the reactor was washed with a solution of $10 \mathrm{mg} \mathrm{L}^{-1}$ hydrogen peroxide and was rinsed three times with distilled water.

\subsection{ROS determination}


Several oxidative agents generated during PEC operation were detected by spectrophotometric methods. A JENWAY 6300 UV-VIS spectrophotometer was used with glass cuvettes of $1 \mathrm{~cm}$ path length.

i) Hydroxyl radicals generated were measured by spectrophotometry following procedure described elsewhere (Cruz-Ortiz et al., 2017; Muff et al., 2011). Briefly, it consists of detecting the bleaching of a solution with $17 \mu \mathrm{M}$ P-nitrosodimethylaniline (RNO) (Sigma-Aldrich) by measuring light absorbance at $440 \mathrm{~nm}$. Quantification was made in the range from 1 to $20 \mu \mathrm{M}$. It has to be considered that the presence of other oxidant could generate interferences in this method.

ii) Free chlorine (FC) was determined following N,N-diethyl-p-phenylenediamine (DPD) method 10069 from $\mathrm{HACH}$. It consists on the addition of DPD powder pillows from $\mathrm{HACH}$ to the sample, mixing for 30 seconds and measuring at $530 \mathrm{~nm}$.

iii) Hydrogen peroxide concentration was determined by direct reaction with titanium (IV) oxysulfate. For that, $2 \mathrm{~mL}$ of $280 \mathrm{mM}$ solution of $\mathrm{TiOSO}_{4}$ (Sigma-Aldrich) were mixed with 2 $\mathrm{mL}$ of sample (Cruz-Ortiz et al., 2017). The yellow complex formed from the reaction of titanium IV oxysulfate with $\mathrm{H}_{2} \mathrm{O}_{2}$ is measured at $410 \mathrm{~nm}$. Absorbance was read after 5 min equilibration time against a standard curve in the $\mathrm{H}_{2} \mathrm{O}_{2}$ concentration range 1-60 $\mathrm{mg} \mathrm{L}^{-1}$.

\section{Results and discussion}

\subsection{Anodised $\mathrm{TiO}_{2}-\mathrm{NTS}$ characterisation}

Figure 2a shows SEM images of the nanotubes fabricated by the electrochemical anodisation of $\mathrm{Ti}$ mesh. There was a reasonable uniform coverage of the mesh with $\mathrm{TiO}_{2}-\mathrm{NT}$ with an average outer diameter of $95.2 \mathrm{~nm}$, inner diameter of $73.6 \mathrm{~nm}$ diameter, tube wall thickness of $21.6 \mathrm{~nm}$ and average length of $1.05 \mu \mathrm{m}$.

The SEM-EDX measurements of the annealed nanotubes show the peaks corresponding to Ti and $\mathrm{O}$ elements, indicating the formation of the $\mathrm{TiO}_{2}$ nanotubes (data not shown). The XRD analysis of the samples was performed on annealed nanotubes, (Figure 2b). As shown in the figure, the major peaks correspond to anatase planes $\mathrm{A}(101)$ and $\mathrm{A}(004)$. Other peaks corresponding to $\mathrm{A}(200)$, rutile $\mathrm{R}(110)$ and titanium metal were obtained. The titanium metal peaks are coming from the Ti substrate used for the nanotubes growth. Presence of significantly less intense rutile peaks indicates that the nanotubes are mostly anatase with very little contribution from rutile phase. 


\section{FIGURE 2}

\subsection{Assessment of boundary effects on PEC cell: dark and photocatalytic (PC) tests}

To discriminate the influence of any possible parameter on the water disinfection and decontamination performance of PEC a series of different tests were carried out. Firstly, the viability of E. coli in the presence of OMCs were assessed in the dark. Results obtained demonstrated that the initial concentration of bacteria $\left(10^{6} \mathrm{CFU} \mathrm{mL} \mathrm{L}^{-1}\right)$ remained constant for $3 \mathrm{~h}$ (Fig. SI-2). This result discarded therefore any toxic effect over bacterial viability due to the presence of $500 \mu \mathrm{g} \mathrm{L}^{-1}$ of each contaminant (including the $158 \mathrm{mg} \mathrm{L}^{-1}$-approximately $5 \mathrm{mM}$ - of methanol added from the OMCs stock solution).

The photocatalytic activity of $\mathrm{TiO}_{2}$-NT to inactivate E. coli and remove OMCs from water was also investigated using the same PEC without applying the electrical bias (open circuit = photocatalysis). Figure $4 \mathrm{a}$ shows a very small decay of $E$. coli concentration in $2 \mathrm{~h}$ of photocatalytic (PC) treatment, attaining only 0.8-Log Reduction Value (LRV) after $2 \mathrm{~h}$ of PC. This low efficiency is not surprising in an immobilized catalyst configuration. It is very well known that its photocatalytic disinfection efficiency is lower compared with similar load of catalyst in slurry, especially if the catalyst is disposed as a flat plate as mode of immobilisation. This is due to the reduced catalytic surface area available ROS generation, and mass transport limitations from bulk solution to the electrode surface.

Prior to any OMCs degradation test, controls were performed to determine dark adsorption of the OMCs on the electrodes. For that, OMCs were added to the reactor leaving in dark during $1 \mathrm{~h}$, being the decay negligible. The removal of the $\sum \mathrm{OMCs}$ by PC during $60 \mathrm{~min}$ of treatment was studied (Figure 4b). The mixture of OMCs illustrated a representative mixture of different anthropogenic contaminants that could be found in surface waters, therefore the $\Sigma$ OMCs was monitored during the experiment which permitted the comparison with different operating conditions. A linear decrease was observed in this case, reaching ca. $70 \%$ of degradation of the mixture, with a zero order rate constant $k=1.07 \pm 0.08\left(10^{-2} \mathrm{~min}^{-1}\right)$. Nevertheless, the removal was not similar for each OMC, a degradation of $57 \%, 60 \%$ and $87 \%$ of TBT, CVP and DCF, respectively were attained (Fig SI-3). After $60 \mathrm{~min}$ of PC treatment, OMCs concentrations were below their limit of quantification (see Table SI-2). TBT and CVP presented similar behaviour, with a slower degradation rates that shows its greater recalcitrant character when compared to DCF, which almost eliminated. The removal of $\sum$ OMCs achieved (ca. 70\%) without system optimisation was near to that established as target by Switzerland regulations for WWTP effluents 
( $80 \%$ of $\sum$ OMCs removal), being a reference for the rest of countries since it is the first water regulation addressing OMCs concern (Bourgin et al., 2018) in Europe.

The effect of background DOC was also followed in another study (Gao et al., 2020) determining that in a concentration higher than $10 \mathrm{mg} \mathrm{L}^{-1}$ produces a decrease in the degradation rates of DCF due to competition for active sites and ROS. The same behavior is described in electrochemical systems (Kapałka et al., 2010; Panizza and Cerisola, 2009) where working in batch mode, low current density (thus generating a low quantity of oxidant) and high concentration of organic matter, zero-order kinetics were observed. In the present study, with at least $60 \mathrm{mg} \mathrm{L}^{-1}$ of DOC, a marked reduction in the degradation efficiency of the PEC for both, organics and bacteria, was expected. In fact, this study is focused on a real water matrix scenario, where naturally present ions and the organic matter limits the process to reduce the OMCs degradation rate to a zero-order kinetics. This effect is even more marked when immobilized catalysts are used, as it was reported by Saggioro et al. (2014), where the kinetic degradation rate of Bisphenol A removal by immobilized $\mathrm{TiO} 2$ in glass spheres drastically decreases in real wastewater (24 $\mathrm{mg} \mathrm{L}^{-1}$ of DOC), following zero order kinetics.'

\subsection{Photoelectrocatalysis with cathode of Pt}

The optimal current density (calculate photocurrent) for the Pt cathode PEC (PEC-Pt) was established by measuring current response in the dark and under UVA irradiation with applied cell potential between $0.0 \mathrm{~V}$ to $1.5 \mathrm{~V}$, using surface water as electrolyte. Figure 3 shows that the photocurrent rises significantly till $0.5 \mathrm{~V}$, from which the increase was moderated reaching a plateau after the application of $1.0 \mathrm{~V}$. Therefore, $1.0 \mathrm{~V}$ was selected as the operating potential for EAP tests, corresponding to a photocurrent response of $3 \mathrm{~mA}$ (estimated current density of $21 \mu \mathrm{A}$ $\left.\mathrm{cm}^{-2}\right)$.

\section{FIGURE 3}

As this is an electrochemical process, the PEC efficiency is clearly influenced by the concentration of salts in the water to be treated, not only due to the impedance presented for the electrical current, but also from the specific ionic content. It has been demonstrated that the ionic species dissolved in the water determine the oxidant species generated during the electrochemical treatment (Farhat et al., 2017, 2018) since ACS are produced from chlorides oxidation and sulphate radicals $\left(E^{0}=2.5-3.1 \mathrm{~V}\right)$ from sulphates, adding their oxidative effect to that of the hydroxyl radicals. 
The content of salts from the actual stream under study (see Table SI-1) was far from the majority of studies previously published, in which highly concentrated solutions of $\mathrm{Na}_{2} \mathrm{SO}_{4}, \mathrm{NaCl}$ or $\mathrm{NaNO}_{3}$, etc., are used as electrolytes, thus the behaviour of our system was very different. The matrix effect is also remarked by Moles et al. (2020) where it was clear the difference between a $\mathrm{NaCl}$ solution and a real effluent as water matrix, since disinfection with saline solution achieved 7-LRV while in the wastewater effluent was reached ca. 1-LRV, evidencing the influence of the water composition in the disinfection process by PEC.

Despite the low salinity of the surface water $\left(697 \mu \mathrm{S} \mathrm{cm}^{-1}\right.$ vs $8.8 \mathrm{mS} \mathrm{cm}^{-1}$ of a $50 \mathrm{mM} \mathrm{Na}_{2} \mathrm{SO}_{4}$ supporting electrolyte solution), the PEC-Pt system gave a 2-LRV in 120 min of treatment as is shown in Figure 4a. In comparison with PC alone, a similar pattern of bacteria inactivation was obtained with PEC-Pt, but with a slight increase on the bacterial reduction at the end of the treatment. This enhancement can be attributed to the enhanced charge carrier separation. The effect of the electrochemical process stand-alone was evaluated and not significant change in $E$. coli concentration was observed, therefore, any detrimental effect of the stand-alone electrochemical process over E. coli was discarded (Fig 4.a and 5.a).

The application of an electrical bias has been reported to give also an enhancement in the degradation of OMCs as compared to PC (Cheng et al., 2016; Nie et al., 2013). In this work no real difference was observed in the rate of OMC degradation with EAP $\left(k=1.15 \pm 0.12\left(10^{-2}\right.\right.$ $\left.\left.\min ^{-1}\right)\right)$ as compared to $\mathrm{PC}\left(k=1.07 \pm 0.08\left(10^{-2} \mathrm{~min}^{-1}\right)\right)$ (Fig. $\left.4 \mathrm{~b}\right)$. This behaviour remarked the influence of the high amount of organic matter provided by the stock solution, that competed with OMCs for oxidizing radicals.

The direct comparison with previous work on the EAP degradation of OMCs is not realistic due differences in experimental parameters (mainly a high OMCs concentration in the range of several $\left.\mathrm{mg} \mathrm{L}^{-1}\right)$. However Mazierski et al. (2019) studied the removal of $0.385 \mathrm{mM}\left(50 \mathrm{mg} \mathrm{L}^{-1}\right)$ of 5-

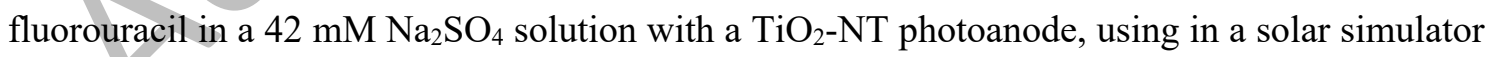
with a Xenon lamp applying an UV-A irradiation of $4.5 \mathrm{~mW} \mathrm{~cm}^{-2}\left(45 \mathrm{~W} \mathrm{~m}^{-2}\right)$. When applied a potential of $1 \mathrm{~V}$, more than 60 min were needed to remove the $80 \%$ of the initial concentration of 5-fluorouracil, approximately the same time as was needed to our system to remove the same percentage starting from a lower concentration of pollutant. In other cases, as Cheng et al. (2016), the treatment time is much longer, since using a $\mathrm{TiO}_{2}-\mathrm{NT}$ anode $\left(4 \mathrm{~cm}^{2}\right)$ and a $35 \mathrm{~W}$ Xenon lamp, needed more than $5 \mathrm{~h}$ to remove the $80 \%$ of $5 \mathrm{mg} \mathrm{L}^{-1}$ of DCF in a $0.1 \mathrm{M}$ solution of $\mathrm{Na}_{2} \mathrm{SO}_{4}$ applying $0.4 \mathrm{~V}$. 


\section{FIGURE 4}

\subsection{Photoelectrocatalysis with cathode of $C$-felt}

The working potential for PEC with C-felt cathode (PEC-C felt) was determined by monitoring the photocurrent response with the cell potential increasing from $0.0 \mathrm{~V}$ to $1.5 \mathrm{~V}$ and observing the maximum photocurrent value (Fig. 3). The photocurrent behaviour was similar to PEC-Pt, reaching the maximum at $1 \mathrm{~V}$, but with a lower current density value, $1.8 \mathrm{~mA}\left(12.5 \mu \mathrm{Acm}^{-2}\right)$ due to the higher resistance of the carbon felt as compared to Ti-Pt mesh.

Figure 5a shows the E. coli inactivation profile obtained by PEC-C felt. Although a lower photocurrent was observed, there was a greater LRV of 2.7 achieved. It has been reported previously that the rate of disinfection is not directly proportional to the photocurrent in EAP (Pablos et al., 2017b). The improvement in the rate of disinfection may be attributed to the selective production of hydrogen peroxide $\left(\mathrm{H}_{2} \mathrm{O}_{2}\right)$ at the carbon cathode.

It is well known that $\mathrm{H}_{2} \mathrm{O}_{2}$ is a disinfectant that even at low concentrations it can enhance the rate of photo-inactivation of microorganisms (Polo-López et al., 2011). This phenomenon is explained by the diffusion of $\mathrm{H}_{2} \mathrm{O}_{2}$ across the cell membrane as it is a non-charged molecule. Once inside the cell, the equilibrium of ROS changes, releasing the iron naturally occurring in cells that reacts with $\mathrm{H}_{2} \mathrm{O}_{2}$ to produce internal ${ }^{\circ} \mathrm{OH}$ which accumulation and reaction with internal structures (DNA, proteins, enzymes, etc) finally determines the cell death (Giannakis et al., 2016). In fact, the use of a carbon cathode for in situ generation of $\mathrm{H}_{2} \mathrm{O}_{2}$ as an enhancement for solar disinfection (SODIS) process was investigated by Jin et al. (2020) that reach approximately 6-LRV on E. coli K12 concentration in $180 \mathrm{~min}$ while 3 -LRV was attained by only SODIS and electrolysis 1-LRV.

For the PEC-C felt system it is possible to calculate the theoretical maximum amount of $\mathrm{H}_{2} \mathrm{O}_{2}$ electrogenerated that could be obtained in the system. Knowing the electrical charge $(Q)$, with the Faraday constant $\left(F, 96485 \mathrm{Q} \mathrm{mol}^{-1}\right)$, the $e^{-}$moles $\left(n_{e}\right)$ can be calculated based on equation 1 . The maximum accumulated $\mathrm{H}_{2} \mathrm{O}_{2}$ that could be generated in our experimental system, assuming that all $e^{-}$are employed in its production, was ca. $15 \mathrm{mg} \mathrm{L}^{-1}$ after $120 \mathrm{~min}$. However, as it was consumed as being generated, we were not able to detect the level of $\mathrm{H}_{2} \mathrm{O}_{2}$ using the titanium oxysulphate method as the limit of quanitifation was only $1 \mathrm{ppm}$.

$Q=n_{e} \cdot F$

Eq. 1 
In addition, $\mathrm{FC}$ is generated simultaneously due to chlorine oxidation, being able to react with the electrogenerated $\mathrm{H}_{2} \mathrm{O}_{2}$ (reaction 1). In fact the use of $\mathrm{H}_{2} \mathrm{O}_{2}$ as quencher for $\mathrm{FC}$ in drinking water is commonly used (Wang et al., 2006). Thus apart from $\mathrm{H}_{2} \mathrm{O}_{2}$ internal diffusion across cell membranes, $\mathrm{H}_{2} \mathrm{O}_{2}$ could generate $\mathrm{O}_{2}$ through reaction 1, so producing ROS according to reactions $2-5$, explaining the subsequently enhance of bacteria inactivation.

$$
\begin{aligned}
& \mathrm{HOCl}+\mathrm{H}_{2} \mathrm{O}_{2} \rightarrow \mathrm{O}_{2}+\mathrm{H}_{2} \mathrm{O}+\mathrm{HCl} \\
& \mathrm{e}_{\mathrm{CB}}{ }^{-}+\mathrm{O}_{2} \rightarrow \mathrm{O}_{2}{ }^{\bullet-} \\
& \mathrm{O}_{2}{ }^{\bullet}+\mathrm{H}^{+} \rightarrow \mathrm{HO}_{2}{ }^{\bullet} \\
& 2 \mathrm{HO}_{2}{ }^{\bullet} \rightarrow \mathrm{H}_{2} \mathrm{O}_{2}+\mathrm{O}_{2} \\
& \mathrm{H}_{2} \mathrm{O}_{2}+\mathrm{O}_{2}{ }^{\bullet} \rightarrow \bullet
\end{aligned}
$$

\section{FIGURE 5}

There was no improvement in the degradation rate of the OMCs using the carbon cathode (Figure $5 b)$. The degradation of the sum of OMCs was similar to that observed with the Pt cathode, with $k=1.17 \pm 0.05\left(10^{-2} \mathrm{~min}^{-1}\right)$. The $\%$ degradation achieved for the individual OMCs was $63 \%$ of TBT, $57 \%$ of CVP and $>90 \%$ of DCF in $60 \mathrm{~min}$ (Figure SI-3).

In other studies it was demonstrated that $\mathrm{H}_{2} \mathrm{O}_{2}$ itself is not able to remove OMCs, as in Michael et al. (2020) where the combination of sunlight and $\mathrm{H}_{2} \mathrm{O}_{2}$, in a concentration of $30 \mathrm{mg} \mathrm{L}^{-1}$, after 5 $\mathrm{h}$ of treatment only achieved the removal of the $46 \%$ of sulfamethoxazole in an urban wastewater with $15 \mathrm{mg} \mathrm{L}^{-1}$ of DOC. Moreover, in Jiménez-Tototzintle et al. (2015), it was studied the effects of $\mathrm{H}_{2} \mathrm{O}_{2}$ addition to a $\mathrm{TiO}_{2}$ supported catalyst for the removal of imazalil, thiabendazole and acetamiprid (200 $\mu \mathrm{g} \mathrm{L}^{-1}$ each) in a wastewater treatment plant effluent with $25.2 \mathrm{mg} \mathrm{L}^{-1}$ of DOC, being required $500 \mathrm{mg} \mathrm{L}^{-1}$ of $\mathrm{H}_{2} \mathrm{O}_{2}$ to achieve a remarkable improvement, evidencing its low efficiency to remove OMCs even acting as electron acceptor. Therefore in our system, where peroxide production is very low, no improvement is expected. Moreover if it reacts with FC generating producing finally ROS, consequently the amount generated will be also very low and, even if they improves the inactivation of bacteria, they will probably not be enough to mineralize the OMCs.

The simultaneous removal of OMCs and E. coli was also investigated aiming to evaluate any possible competition effect between both targets during the PEC-C felt treatment. Results are shown in Figure 5a and b for E. coli and OMCs, respectively. 
The PEC-C felt system for the simultaneous treatment improved the rate of E. coli inactivation as compared to the disinfection results in the absence of OMCs. The detection limit was reached in 90 min of treatment (approximately 4.5-LRV). The enhancement in bacterial inactivation could be cause due to the methanol added from the OMCs stock solution. On the one hand the oxidation of methanol generates formaldehyde (HCHO) (Pablos et al., 2014) which is bactericidal even at low concentrations ( $\mathrm{LC}_{50}$ for $E$. coli $=1 \mathrm{mg} \mathrm{L}^{-1}$ or $33 \mu \mathrm{M}$ ) (Bae et al., 2008; Verschueren, 2001). On the other hand, methanol is a hole scavenger that increases the photocurrent and may led to the generation of more $\mathrm{H}_{2} \mathrm{O}_{2}$ at the cathode. The action of hole scavengers is described in detail in section 3.6. Regarding $\sum O M C s$ a slight enhancement is observed with a rate constant of $k=1.38$ $\pm 0.07\left(10^{-2} \mathrm{~min}^{-1}\right)$.

\subsection{Oxidant species generated during PEC}

The generation oxidant species was monitored during PC (as reference) and for EAP with the carbon electrode. Figure 6a shows the results of of RNO bleaching measured ${ }^{\circ} \mathrm{OH}$ when using PEC-C felt system in comparison with PC. It should be considered that in waters containing chlorides, ACS are produced which are able to bleach RNO by themselves, being an interference for ${ }^{\circ} \mathrm{OH}$ determination (Muff et al., 2011). For that reason the RNO bleaching was considered as a parameter to evaluate the oxidative power of the electrochemical system.Specifically, after 30 min of EAP with the carbon cathode, $66 \%$ of the RNO was removed while $27 \%$ with PC. These results support the benefits of EAP for the inactivation and degradation of E. coli and OMCs (Fig. $5 \mathrm{a}$ and 5b, respectively) in comparison with PC in water. The application of an external electrical bias serves to separate the charge carriers and therefore should increase oxidant species production at the photoanode.

$\mathrm{H}_{2} \mathrm{O}_{2}$ quantification in the presence of background organic matter, OMCs and bacteria was not feasible, as probably the amount generated by the cathode was consumed during the electrochemical assisted process and remained below the quantification limit $\left(1 \mathrm{mg} \mathrm{L}^{-1)}\right.$. To confirm that $\mathrm{H}_{2} \mathrm{O}_{2}$ is generated at the carbon cathode, the PEC cell was used with the carbon-felt as cathode under the same conditions irradiance, voltage, milli-Q water and sodium sulphate $\left(697 \mathrm{uS} \mathrm{cm}^{-1}\right)$ to produce the same current density but without any model pollutant or pathogen present. Then the $\mathrm{H}_{2} \mathrm{O}_{2}$ concentration was measured at times $60 \mathrm{~min}\left(1.32 \mathrm{mg} \mathrm{L}^{-1}\right)$ and $120 \mathrm{~min}$ ( $2.40 \mathrm{mg} \mathrm{L}^{-1}$ ). The amount of $\mathrm{H}_{2} \mathrm{O}_{2}$ generated is quite small compared with the theoretical Faradaic yield (ca. $15 \mathrm{mg} \mathrm{L}^{-1}$ at $120 \mathrm{~min}$ ). However, during the reaction some peroxide generated may be consumed by reduction at the cathode or oxidation at the photoanode. Other authors report small values of $\mathrm{H}_{2} \mathrm{O}_{2}$ also. For example, Panizza (2010) reported that carbon-based materials have also been widely used as cathodes in indirect electrolysis of organics generating in situ hydrogen 
peroxide, by two-electron reduction of oxygen on the cathode surface $\left(\mathrm{O}_{2}+2 \mathrm{H}^{+}+2 \mathrm{e}^{-} \rightarrow \mathrm{H}_{2} \mathrm{O}_{2}\right)$. They reported that while carbon and graphite exhibited good electrochemical activities for oxygen reduction, they showed low catalytic activity for hydrogen peroxide decomposition. Zhou et al. (2019) reported that carbon-based materials (e.g. carbon-felt) are the most commonly used materials for $\mathrm{H}_{2} \mathrm{O}_{2}$ generation by $\mathrm{O}_{2}$ electroreduction; while Brillas et al. (2010) also reported the use of carbon-based cathodes for $\mathrm{O}_{2}$ electroreduction and $\mathrm{H}_{2} \mathrm{O}_{2}$ electrogeneration in their study about electro-Fenton with in-situ generated $\mathrm{H}_{2} \mathrm{O}_{2}$. Recently, Ye et al. (2019) used a carbon-felt cathode for $\mathrm{H}_{2} \mathrm{O}_{2}$ production working at natural $\mathrm{pH}$ - similar conditions as our system recognizing that the $\mathrm{H}_{2} \mathrm{O}_{2}$ concentration achieved with carbon-felt immersed in the solution, where the air is sparged to ensure $\mathrm{O}_{2}$ saturation, was lower than air diffusion cathodes but enough to develop electro-Fenton process as is also able to regenerate Fe. In our research it was also noted that the generated $\mathrm{H}_{2} \mathrm{O}_{2}$ is very close to the detection limit and very hard to measure when other chemical compounds of reactive species are present.

The generation of FC measured with the PEC-C felt and PC is shown in Figure 6b. It is observed that values of FC detected was higher in the case of EAP than in PC.FC is formed by the oxidation of chloride present in the surface water $\left(18.4 \mathrm{mg} \mathrm{L}^{-1}\right)$. With EAP, the separation of charge carriers means the holes are longer lived and more likely to react with chloride. Moreover, according to reaction 1, part of the $\mathrm{FC}$ produced is quenched by the electrogenerated $\mathrm{H}_{2} \mathrm{O}_{2}$, so the measurement represents residual FC in the solution. The concentration of FC detected during PEC-C felt treatment was very low $\left(<0.5 \mathrm{mg} \mathrm{L}^{-1}\right)$ in $30 \mathrm{~min}$ of treatment. This is below the recommended free chlorine level for residual disinfection of water (WHO, 2017).

\section{FIGURE 6}

\subsection{Influence of hole acceptors in PEC disinfection}

In this study, the bacteria inactivation by PEC-C felt cathode was tested in the presence of $5 \mathrm{mM}$ of methanol and acetate as hole-acceptors (Fig. 7), as this was the concentration of methanol added with the stock solution of OMCs. In EAP processes with $\mathrm{TiO}_{2}$ photoanodes, hole-acceptors such as methanol and acetate, generate an increase in the photocurrent studied in detail by Byrne et al. (1998). The one electron oxidation of methanol generates a radical which injects a second electron to the conduction band, giving rise to photocurrent doubling. However, acetate is not a current doubling agent. For that reason, in our study the average of photocurrent with methanol was a $38 \%$ higher than without hole scavengers while for acetate was a $20 \%$ higher. 
Regarding disinfection, the inactivation rates obtained in the presence of hole acceptors are much higher (Fig. 7). For methanol, this enhancement was previously explained due to the formation of formaldehyde which is highly toxic for microorganism and the generation of ROS derived from oxygen reduction reactions (reactions 2-5) while for acetate, the improvement have to be caused mainly for the ROS.

That way, extracellular ROS and intracellular ${ }^{\circ} \mathrm{OH}$ can inactivate bacteria through DNA/RNA damage, membrane rupture, interruption of respiratory pathways or increased ion permeability (Sun et al., 2016). Previous studies pointed out the sensitivity of E. coli to $\mathrm{H}_{2} \mathrm{O}_{2}$ (Morais et al., 2016) and the effective inactivation in the presence of superoxide radicals $\left(\mathrm{O}_{2}{ }^{-}\right.$) (Gupta et al., 2019). Therefore, using a hole scavenger and carbon felt as a cathode simultaneously could lead to a lower electron-hole recombination rate, allowing increasing the number of photoinduced electrons that are able to reduce oxygen and produce higher concentrations of ROS, such as $\mathrm{H}_{2} \mathrm{O}_{2}$ and $\mathrm{O}_{2}{ }^{-}$.

\section{FIGURE 7}

\section{Conclusions}

PEC systems based on $\mathrm{TiO}_{2}$-NTs has been evaluated as an alternative for the treatment of real surface water, in which salt concentration is substantially lower than in the solutions used as supporting electrolytes, eg., $\mathrm{Na}_{2} \mathrm{SO}_{4}$ that is commonly used in concentrations of $50 \mathrm{mM}$ or higher. This research has confirmed the suitability of using C-felt cathode for a PEC cell as promising alternative to Pt. Carbon-based electrodes at the same current, without additional energy cost, are able to simultaneously produce $\mathrm{H}_{2} \mathrm{O}_{2}$, improving current efficiency of the system. The simultaneous removal of OMCs and E. Coli has been successfully proven in the PEC - C felt system for surface water depuration being the first step for the application of this system in conditions closer to reality. The presence of a significant amount of background organic matter $\left(60 \mathrm{mg} \mathrm{L}^{-1}\right)$ had a critical effect on the efficiency since it caused a scavenger effect for the oxidant radicals. Despite this, $70 \%$ degradation of the OMCs was reached. The study of oxidizing species confirmed that the generation of $\mathrm{H}_{2} \mathrm{O}_{2}$ and $\mathrm{FC}$ represents a great improvement for disinfection purposes, despite they do not significantly affect the removal of OMCs. Nevertheless, it is important to highlight that further research must be tackled to better distinguish and define the inactivation mechanism when PEC-C felt system is applied.

\section{Acknowledgements}


This research has received funding from the European Union's Horizon 2020 via the Marie Curie Action under the grant agreement number 734560 (ALICE), and the research and innovation program under the grant agreement number 820718 , which is jointly funded by the European Commission and the Department of Science and Technology of India (PANIWATER).

\section{Declarations of interest: none}

\section{References}

Bae, E., Lee, J.W., Hwang, B.H., Yeo, J., Yoon, J., Cha, H.J., Choi, W., 2008. Photocatalytic bacterial inactivation by polyoxometalates. Chemosphere 72, 174-181.

Baram, N., Starosvetsky, D., Starosvetsky, J., Epshtein, M., Armon, R., Ein-Eli, Y., 2009. Enhanced inactivation of E. coli bacteria using immobilized porous $\mathrm{TiO}_{2}$ photoelectrocatalysis. Electrochim. Acta 54, 3381-3386.

Bourgin, M., Beck, B., Boehler, M., Borowska, E., Fleiner, J., Salhi, E., Teichler, R., von Gunten, U., Siegrist, H., McArdell, C.S., 2018. Evaluation of a full-scale wastewater treatment plant upgraded with ozonation and biological post-treatments: Abatement of micropollutants, formation of transformation products and oxidation by-products. Water Res. 129, 486-498.

Brillas, E., Sirés, I., Cabot, P.L.s., 2010. Use of both anode and cathode reactions in wastewater treatment, Electrochemistry for the Environment. Springer, pp. 515-552.

Byrne, J.A., Davidson, A., Dunlop, P.S.M., Eggins, B.R., 2002. Water treatment using nanocrystalline $\mathrm{TiO}_{2}$ electrodes. J Photoch Photobio A 148, 365-374.

Byrne, J.A., Eggins, B.R., Linquette-Mailley, S., Dunlop, P.S.M., 1998. The effect of hole acceptors on the photocurrent response of particulate $\mathrm{TiO}_{2}$ anodes. Analyst 123, 2007-2012.

Cardoso, J.C., Lizier, T.M., Zanoni, M.V.B., 2010. Highly ordered $\mathrm{TiO}_{2}$ nanotube arrays and photoelectrocatalytic oxidation of aromatic amine. Appl Catal B-Environ 99, 96-102.

Cheng, X., Cheng, Q., Deng, X., Wang, P., Liu, H., 2016. A facile and novel strategy to synthesize reduced $\mathrm{TiO}_{2}$ nanotubes photoelectrode for photoelectrocatalytic degradation of diclofenac. Chemosphere 144, 888-894.

Cotillas, S., Llanos, J., Rodrigo, M.A., Canizares, P., 2015. Use of carbon felt cathodes for the electrochemical reclamation of urban treated wastewaters. Appl Catal B-Environ 162, 252-259. Cruz-Ortiz, B.R., Hamilton, J.W.J., Pablos, C., Díaz-Jiménez, L., Cortés-Hernández, D.A., Sharma, P.K., Castro-Alférez, M., Fernández-Ibañez, P., Dunlop, P.S.M., Byrne, J.A., 2017. Mechanism of photocatalytic disinfection using titania-graphene composites under UV and visible irradiation. Chem. Eng. J. 316, 179-186. 
Farhat, A., Keller, J., Tait, S., Radjenovic, J., 2017. Assessment of the impact of chloride on the formation of chlorinated by-products in the presence and absence of electrochemically activated sulfate. Chem. Eng. J. 330, 1265-1271.

Farhat, A., Keller, J., Tait, S., Radjenovic, J., 2018. Oxidative capacitance of sulfate-based borondoped diamond electrochemical system. Electrochem. Commun. 89, 14-18.

Gao, L., Zhou, B., Wang, F., Yuan, R., Chen, H., Han, X., 2020. Effect of dissolved organic matters and inorganic ions on $\mathrm{TiO}_{2}$ photocatalysis of diclofenac: mechanistic study and degradation pathways. Environ Sci Pollut Res Int 27, 2044-2053.

Giannakis, S., Polo López, M.I., Spuhler, D., Sánchez Pérez, J.A., Fernández Ibáñez, P., Pulgarin, C., 2016. Solar disinfection is an augmentable, in situ -generated photo-Fenton reaction-Part 1: A review of the mechanisms and the fundamental aspects of the process. Appl Catal B-Environ 199, 199-223.

Gupta, R., Modak, J.M., Madras, G., 2019. Behavioral analysis of simultaneous photo-electrocatalytic degradation of antibiotic resistant $\mathrm{E}$. coli and antibiotic via $\mathrm{ZnO} / \mathrm{CuI}$ : a kinetic and mechanistic study. Nanoscale Advances 1, 3992-4008.

Jiménez-Tototzintle, M., Oller, I., Hernández-Ramírez, A., Malato, S., Maldonado, M.I., 2015. Remediation of agro-food industry effluents by biotreatment combined with supported $\mathrm{TiO}_{2} / \mathrm{H}_{2} \mathrm{O}_{2}$ solar photocatalysis. Chem. Eng. J. 273, 205-213.

Jin, Y., Shi, Y., Chen, Z., Chen, R., Chen, X., Zheng, X., Liu, Y., Ding, R., 2020. Enhancement of solar water disinfection using $\mathrm{H} 2 \mathrm{O} 2$ generated in situ by electrochemical reduction. Appl Catal B-Environ 267.

Kapałka, A., Fóti, G., Comninellis, C., 2010. Basic principles of the electrochemical mineralization of organic pollutants for wastewater treatment, Electrochemistry for the Environment. Springer, pp. 1-23.

Le, T.X.H., Bechelany, M., Cretin, M., 2017. Carbon felt based-electrodes for energy and environmental applications: a review. Carbon 122, 564-591.

Leng, W.H., Zhu, W.C., Ni, J., Zhang, Z., Zhang, J.Q., Cao, C.N., 2006. Photoelectrocatalytic destruction of organics using $\mathrm{TiO} 2$ as photoanode with simultaneous production of $\mathrm{H} 2 \mathrm{O} 2$ at the cathode. Appl Catal A-Gen 300, 24-35.

Liu, X., Han, Y., Li, G., Zhang, H., Zhao, H., 2013. Instant inactivation and rapid decomposition of Escherichia coli using a high efficiency $\mathrm{TiO} 2$ nanotube array photoelectrode. RSC Advances 3, 20824-20828.

Mazierski, P., Borzyszkowska, A.F., Wilczewska, P., Bialk-Bielinska, A., Zaleska-Medynska, A., Siedlecka, E.M., Pieczynska, A., 2019. Removal of 5-fluorouracil by solar-driven photoelectrocatalytic oxidation using $\mathrm{Ti} / \mathrm{TiO}_{2}(\mathrm{NT})$ photoelectrodes. Water Res. 157, 610-620. 
Michael, S.G., Michael-Kordatou, I., Nahim-Granados, S., Polo-López, M.I., Rocha, J., MartínezPiernas, A.B., Fernández-Ibáñez, P., Agüera, A., Manaia, C.M., Fatta-Kassinos, D., 2020. Investigating the impact of UV-C/ $\mathrm{H}_{2} \mathrm{O}_{2}$ and sunlight $/ \mathrm{H}_{2} \mathrm{O}_{2}$ on the removal of antibiotics, antibiotic resistance determinants and toxicity present in urban wastewater. Chem. Eng. J. 388.

Moles, S., Valero, P., Escuadra, S., Mosteo, R., Gomez, J., Ormad, M.P., 2020. Performance comparison of commercial $\mathrm{TiO}_{2}$ : separation and reuse for bacterial photo-inactivation and emerging pollutants photo-degradation. Environ Sci Pollut Res Int.

Morais, L.A., Adán, C., Araujo, A.S., Guedes, A.P.M.A., Marugán, J., 2016. Photocatalytic Activity of Suspended and Immobilized Niobium Oxide for Methanol Oxidation and Escherichia coli Inactivation. J. Adv. Oxid. Technol. 19, 256-265.

Moreira, F.C., Boaventura, R.A.R., Brillas, E., Vilar, V.J.P., 2017. Electrochemical advanced oxidation processes: a review on their application to synthetic and real wastewaters. Appl. Catal. B-Environ. 202, 217-261.

Muff, J., Bennedsen, L.R., Søgaard, E.G., 2011. Study of electrochemical bleaching of pnitrosodimethylaniline and its role as hydroxyl radical probe compound. J. Appl. Electrochem. 41, 599-607.

Nie, X., Chen, J., Li, G., Shi, H., Zhao, H., Wong, P.-K., An, T., 2013. Synthesis and characterization of $\mathrm{TiO} 2$ nanotube photoanode and its application in photoelectrocatalytic degradation of model environmental pharmaceuticals. J. Chem. Technol. Biot. 88, 1488-1497.

Pablos, C., Marugán, J., Adán, C., Osuna, M., van Grieken, R., 2017a. Performance of $\mathrm{TiO}_{2}$ photoanodes toward oxidation of methanol and E. coli inactivation in water in a scaled-up photoelectrocatalytic reactor. Electrochim. Acta 258, 599-606.

Pablos, C., Marugán, J., van Grieken, R., Adán, C., Riquelme, A., Palma, J., 2014. Correlation between photoelectrochemical behaviour and photoelectrocatalytic activity and scaling-up of P25- $\mathrm{TiO}_{2}$ electrodes. Electrochim. Acta 130, 261-270.

Pablos, C., Marugán, J., van Grieken, R., Dunlop, P., Hamilton, J., Dionysiou, D., Byrne, J., 2017b. Electrochemical enhancement of photocatalytic disinfection on aligned $\mathrm{TiO}_{2}$ and nitrogen doped $\mathrm{TiO}_{2}$ nanotubes. Molecules 22, 704.

Panizza, M., 2010. Importance of electrode material in the electrochemical treatment of wastewater containing organic pollutants, in: Comninellis, C., Chen, G. (Eds.), Electrochemistry for the Environment. Springer, pp. 25-54.

Panizza, M., Cerisola, G., 2009. Direct and mediated anodic oxidation of organic pollutants. Chem. Rev. 109, 12, 6541-6569.

Polo-López, M.I., García-Fernández, I., Oller, I., Fernández-Ibáñez, P., 2011. Solar disinfection of fungal spores in water aided by low concentrations of hydrogen peroxide. Photoch. Photobio. Sci. 10, 381-388. 
Quan, X., Ruan, X., Zhao, H., Chen, S., Zhao, Y., 2007. Photoelectrocatalytic degradation of pentachlorophenol in aqueous solution using a $\mathrm{TiO}_{2}$ nanotube film electrode. Environ. Pollut. 147, 409-414.

Saggioro, E.M., Oliveira, A.S., Pavesi, T., Tototzintle, M.J., Maldonado, M.I., Correia, F.V., Moreira, J.C., 2014. Solar CPC pilot plant photocatalytic degradation of bisphenol A in waters and wastewaters using suspended and supported- $\mathrm{TiO}_{2}$. Influence of photogenerated species. Environ. Sci. Pollut. R. 21, 12112-12121.

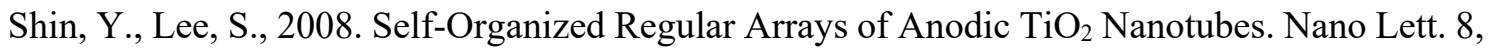
3171-3173.

Sun, H., Li, G., An, T., Zhao, H., Wong, P.K., 2016. Unveiling the photoelectrocatalytic inactivation mechanism of Escherichia coli: Convincing evidence from responses of parent and anti-oxidation single gene knockout mutants. Water Res. 88, 135-143.

Verschueren, K., 2001. Handbook of environmental data on organic chemicals: Vol. 1. John Wiley and Sons, Inc.

Wang, L., Hung, Y.-T., Shammas, N., 2006. Advanced Physicochemical Treatment Processes.

WHO, W.H.O., 2017. Guidelines for drinking-water quality. Fourth edition incorporating the first adenddum.

Xie, Y.B., Li, X.Z., 2006. Interactive oxidation of photoelectrocatalysis and electro-Fenton for azo dye degradation using $\mathrm{TiO}_{2}-\mathrm{Ti}$ mesh and reticulated vitreous carbon electrodes. Mater. Chem. Phys. 95, 39-50.

Ye, Z., Brillas, E., Centellas, F., Cabot, P.L., Sirés, I., 2019. Electro-Fenton process at mild pH using Fe(III)-EDDS as soluble catalyst and carbon felt as cathode. Appl. Catal. B- Environ. 257. Zhou, W., Meng, X., Gao, J., Alshawabkeh, A.N., 2019. Hydrogen peroxide generation from O2 electroreduction for environmental remediation: A state-of-the-art review. Chemosphere 225, 588-607. 
Bae, E., Lee, J.W., Hwang, B.H., Yeo, J., Yoon, J., Cha, H.J., Choi, W., 2008. Photocatalytic bacterial inactivation by polyoxometalates. Chemosphere 72, 174-181.

Baram, N., Starosvetsky, D., Starosvetsky, J., Epshtein, M., Armon, R., Ein-Eli, Y., 2009. Enhanced inactivation of E. coli bacteria using immobilized porous $\mathrm{TiO}_{2}$ photoelectrocatalysis. Electrochim. Acta 54, 3381-3386.

Bourgin, M., Beck, B., Boehler, M., Borowska, E., Fleiner, J., Salhi, E., Teichler, R., von Gunten, U., Siegrist, H., McArdell, C.S., 2018. Evaluation of a full-scale wastewater treatment plant upgraded with ozonation and biological post-treatments: Abatement of micropollutants, formation of transformation products and oxidation by-products. Water Res. 129, 486-498.

Byrne, J.A., Davidson, A., Dunlop, P.S.M., Eggins, B.R., 2002. Water treatment using nanocrystalline $\mathrm{TiO}_{2}$ electrodes. J Photoch Photobio A 148, 365-374.

Byrne, J.A., Eggins, B.R., Linquette-Mailley, S., Dunlop, P.S.M., 1998. The effect of hole acceptors on the photocurrent response of particulate $\mathrm{TiO}_{2}$ anodes. Analyst 123, $2007-$ 2012.

Cardoso, J.C., Lizier, T.M., Zanoni, M.V.B., 2010. Highly ordered $\mathrm{TiO}_{2}$ nanotube arrays and photoelectrocatalytic oxidation of aromatic amine. Appl Catal B-Environ 99, 96-102.

Cheng, X., Cheng, Q., Deng, X., Wang, P., Liu, H., 2016. A facile and novel strategy to synthesize reduced $\mathrm{TiO} 2$ nanotubes photoelectrode for photoelectrocatalytic degradation of diclofenac. Chemosphere 144, 888-894.

Cotillas, S., Llanos, J., Rodrigo, M.A., Canizares, P., 2015. Use of carbon felt cathodes for the electrochemical reclamation of urban treated wastewaters. Appl Catal B-Environ 162, 252259.

Cruz-Ortiz, B.R., Hamilton, J.W.J., Pablos, C., Díaz-Jiménez, L., Cortés-Hernández, D.A., Sharma, P.K., Castro-Alférez, M., Fernández-Ibañez, P., Dunlop, P.S.M., Byrne, J.A., 2017. Mechanism of photocatalytic disinfection using titania-graphene composites under UV and visible irradiation. Chem. Eng. J. 316, 179-186.

Farhat, A., Keller, J., Tait, S., Radjenovic, J., 2017. Assessment of the impact of chloride on the formation of chlorinated by-products in the presence and absence of electrochemically activated sulfate. Chem. Eng. J. 330, 1265-1271.

Farhat, A., Keller, J., Tait, S., Radjenovic, J., 2018. Oxidative capacitance of sulfate-based borondoped diamond electrochemical system. Electrochem. Commun. 89, 14-18.

Gao, L., Zhou, B., Wang, F., Yuan, R., Chen, H., Han, X., 2020. Effect of dissolved organic matters and inorganic ions on $\mathrm{TiO}_{2}$ photocatalysis of diclofenac: mechanistic study and degradation pathways. Environ Sci Pollut Res Int 27, 2044-2053.

Giannakis, S., Polo López, M.I., Spuhler, D., Sánchez Pérez, J.A., Fernández Ibáñez, P., Pulgarin, C., 2016. Solar disinfection is an augmentable, in situ -generated photo-Fenton reaction- 
Part 1: A review of the mechanisms and the fundamental aspects of the process. Appl Catal B-Environ 199, 199-223.

Gupta, R., Modak, J.M., Madras, G., 2019. Behavioral analysis of simultaneous photo-electrocatalytic degradation of antibiotic resistant $\mathrm{E}$. coli and antibiotic via $\mathrm{ZnO} / \mathrm{CuI}$ : a kinetic and mechanistic study. Nanoscale Advances 1, 3992-4008.

Jiménez-Tototzintle, M., Oller, I., Hernández-Ramírez, A., Malato, S., Maldonado, M.I., 2015. Remediation of agro-food industry effluents by biotreatment combined with supported $\mathrm{TiO}_{2} / \mathrm{H}_{2} \mathrm{O}_{2}$ solar photocatalysis. Chem. Eng. J. 273, 205-213.

Jin, Y., Shi, Y., Chen, Z., Chen, R., Chen, X., Zheng, X., Liu, Y., Ding, R., 2020. Enhancement of solar water disinfection using $\mathrm{H}_{2} \mathrm{O}_{2}$ generated in situ by electrochemical reduction. Appl Catal B-Environ 267.

Le, T.X.H., Bechelany, M., Cretin, M., 2017. Carbon felt based-electrodes for energy and environmental applications: a review. Carbon 122, 564-591.

Leng, W.H., Zhu, W.C., Ni, J., Zhang, Z., Zhang, J.Q., Cao, C.N., 2006. Photoelectrocatalytic destruction of organics using $\mathrm{TiO}_{2}$ as photoanode with simultaneous production of $\mathrm{H}_{2} \mathrm{O}_{2}$ at the cathode. Appl Catal A-Gen 300, 24-35.

Liu, X., Han, Y., Li, G., Zhang, H., Zhao, H., 2013. Instant inactivation and rapid decomposition of Escherichia coli using a high efficiency $\mathrm{TiO}_{2}$ nanotube array photoelectrode. RSC Advances 3, 20824-20828.

Mazierski, P., Borzyszkowska, A.F., Wilczewska, P., Bialk-Bielinska, A., Zaleska-Medynska, A., Siedlecka, E.M., Pieczynska, A., 2019. Removal of 5-fluorouracil by solar-driven photoelectrocatalytic oxidation using $\mathrm{Ti} / \mathrm{TiO}_{2}(\mathrm{NT})$ photoelectrodes. Water Res. 157, 610620.

Michael, S.G., Michael-Kordatou, I., Nahim-Granados, S., Polo-López, M.I., Rocha, J., MartínezPiernas, A.B., Fernández-Ibáñez, P., Agüera, A., Manaia, C.M., Fatta-Kassinos, D., 2020. Investigating the impact of $\mathrm{UV}-\mathrm{C} / \mathrm{H}_{2} \mathrm{O}_{2}$ and sunlight $/ \mathrm{H}_{2} \mathrm{O}_{2}$ on the removal of antibiotics, antibiotic resistance determinants and toxicity present in urban wastewater. Chem. Eng. J. 388,124383

Moles, S., Valero, P., Escuadra, S., Mosteo, R., Gomez, J., Ormad, M.P., 2020. Performance comparison of commercial $\mathrm{TiO}_{2}$ : separation and reuse for bacterial photo-inactivation and emerging pollutants photo-degradation. Environ Sci Pollut Res 27, 9099-9113

Morais, L.A., Adán, C., Araujo, A.S., Guedes, A.P.M.A., Marugán, J., 2016. Photocatalytic Activity of Suspended and Immobilized Niobium Oxide for Methanol Oxidation and Escherichia coli Inactivation. J Adv Oxid Technol 19, 256-265. 
Moreira, F.C., Boaventura, R.A.R., Brillas, E., Vilar, V.J.P., 2017. Electrochemical advanced oxidation processes: a review on their application to synthetic and real wastewaters. Appl Catal B-Environ 202, 217-261.

Muff, J., Bennedsen, L.R., Søgaard, E.G., 2011. Study of electrochemical bleaching of pnitrosodimethylaniline and its role as hydroxyl radical probe compound. J. Appl. Electrochem. 41, 599-607.

Nie, X., Chen, J., Li, G., Shi, H., Zhao, H., Wong, P.-K., An, T., 2013. Synthesis and characterization of $\mathrm{TiO} 2$ nanotube photoanode and its application in photoelectrocatalytic degradation of model environmental pharmaceuticals. J Chem Technol Biot 88, 1488-1497.

Pablos, C., Marugán, J., Adán, C., Osuna, M., van Grieken, R., 2017a. Performance of $\mathrm{TiO}_{2}$ photoanodes toward oxidation of methanol and $\mathrm{E}$. coli inactivation in water in a scaled-up photoelectrocatalytic reactor. Electrochim. Acta 258, 599-606.

Pablos, C., Marugán, J., van Grieken, R., Adán, C., Riquelme, A., Palma, J., 2014. Correlation between photoelectrochemical behaviour and photoelectrocatalytic activity and scaling-up of $\mathrm{P} 25-\mathrm{TiO}_{2}$ electrodes. Electrochim. Acta 130, 261-270.

Pablos, C., Marugán, J., van Grieken, R., Dunlop, P., Hamilton, J., Dionysiou, D., Byrne, J., 2017b. Electrochemical enhancement of photocatalytic disinfection on aligned $\mathrm{TiO}_{2}$ and nitrogen doped $\mathrm{TiO}_{2}$ nanotubes. Molecules 22, 704.

Panizza, M., 2010. Importance of electrode material in the electrochemical treatment of wastewater containing organic pollutants, in: Comninellis, C., Chen, G. (Eds.), Electrochemistry for the Environment. Springer, pp. 25-54.

Polo-López, M.I., García-Fernández, I., Oller, I., Fernández-Ibáñez, P., 2011. Solar disinfection of fungal spores in water aided by low concentrations of hydrogen peroxide. Photoch Photobio Sci 10, 381-388.

Quan, X., Ruan, X., Zhao, H., Chen, S., Zhao, Y., 2007. Photoelectrocatalytic degradation of pentachlorophenol in aqueous solution using a TiO2 nanotube film electrode. Environ. Pollut. 147, 409-414.

Shin, Y., Lee, S., 2008. Self-Organized Regular Arrays of Anodic TiO2 Nanotubes. Nano Lett. $8,3171-3173$.

Sun, H., Li, G., An, T., Zhao, H., Wong, P.K., 2016. Unveiling the photoelectrocatalytic inactivation mechanism of Escherichia coli: Convincing evidence from responses of parent and anti-oxidation single gene knockout mutants. Water Res. 88, 135-143.

Verschueren, K., 2001. Handbook of environmental data on organic chemicals: Vol. 1. John Wiley and Sons, Inc.

Wang, L., Hung, Y.-T., Shammas, N., 2006. Advanced Physicochemical Treatment Processes. 
WHO, W.H.O., 2017. Guidelines for drinking-water quality. Fourth edition incorporating the first adenddum.

Xie, Y.B., Li, X.Z., 2006. Interactive oxidation of photoelectrocatalysis and electro-Fenton for azo dye degradation using $\mathrm{TiO}_{2}-\mathrm{Ti}$ mesh and reticulated vitreous carbon electrodes. Mater. Chem. Phys. 95, 39-50.
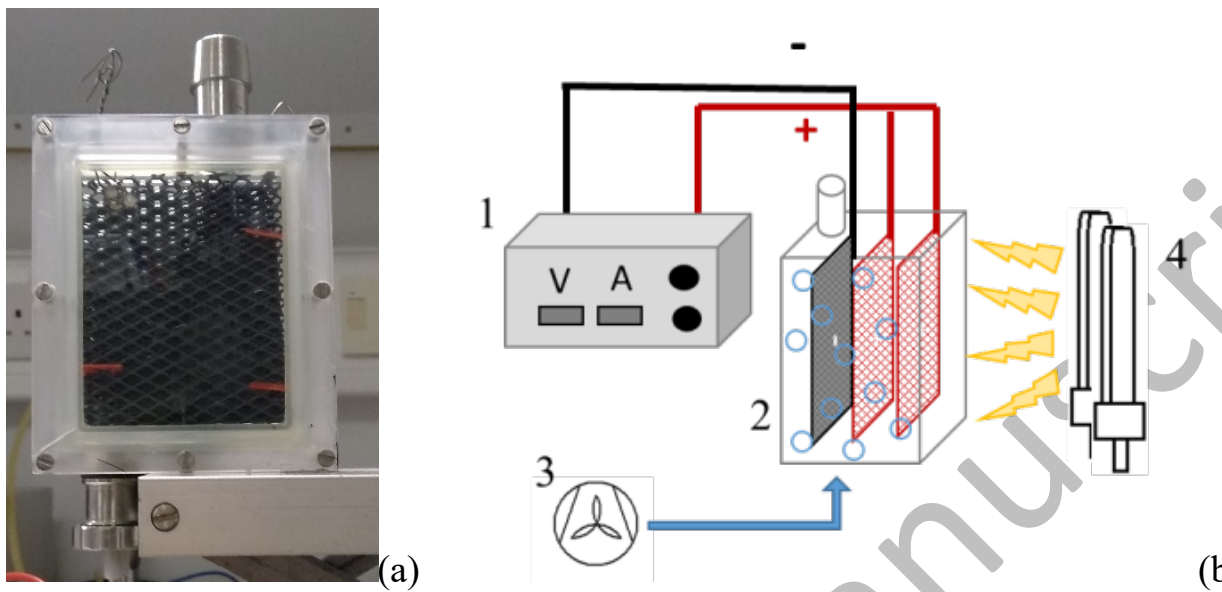

Figure 1. a) photograph of PEC reactor b) Experimental setup: (1) power supply (2) PEC cell (cathode in black, anodes in red), (3) air-blower, (4) UVA lamps. 

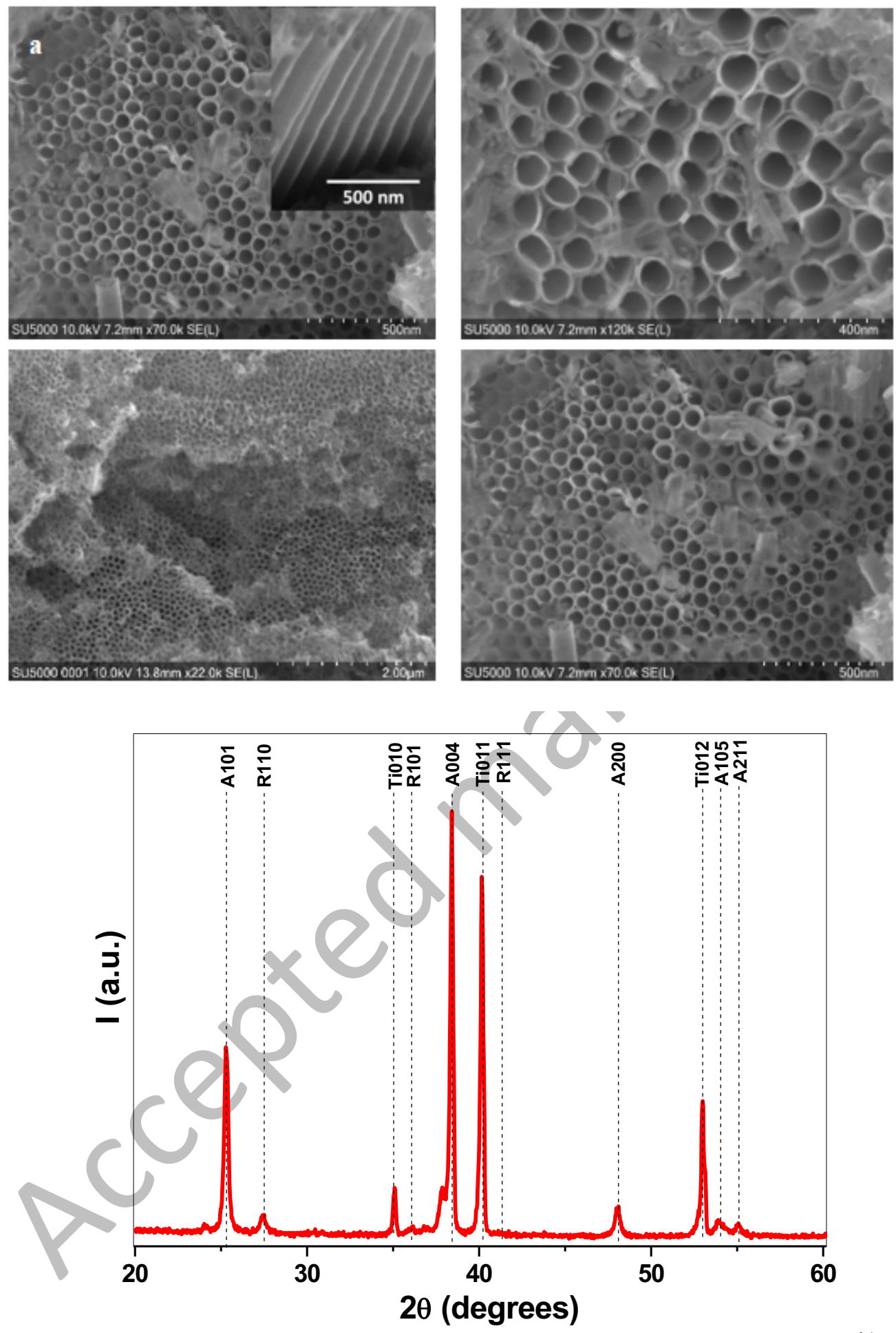

a)

b)

Figure 2. Characterization of $\mathrm{TiO}_{2}-\mathrm{NTs}$ prepared by electrochemical anodization of Ti mesh: a) SEM images with inset(a) view of cross-section of the nanotubes and b) XRD analysis. 


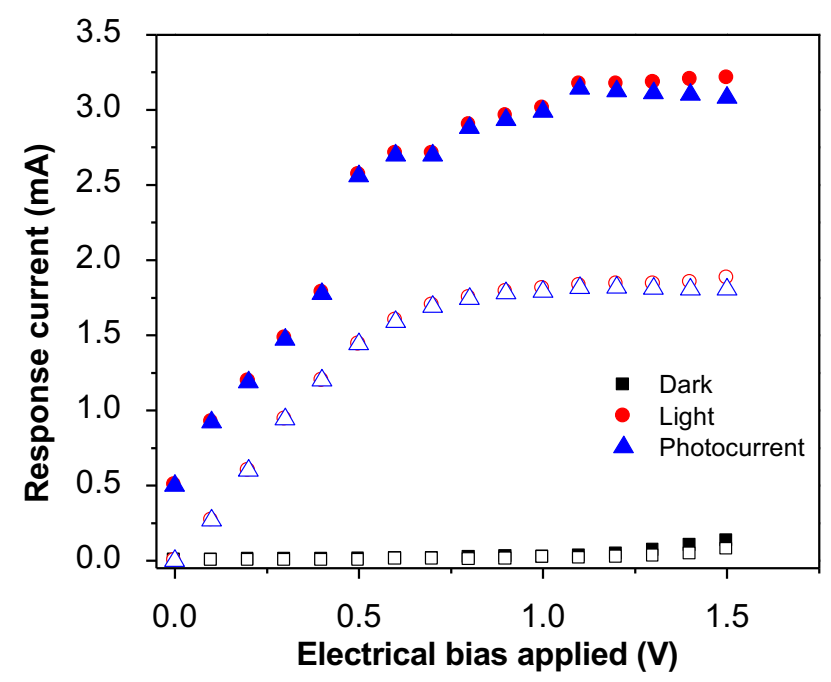

Figure 3. Response current densities in dark and under radiation, and the calculated photocurrent, obtained by the application of a serial of potentials from 0 to $1.5 \mathrm{~V}$ using a Pt cathode (full symbol) and C-felt cathode (open symbol). 

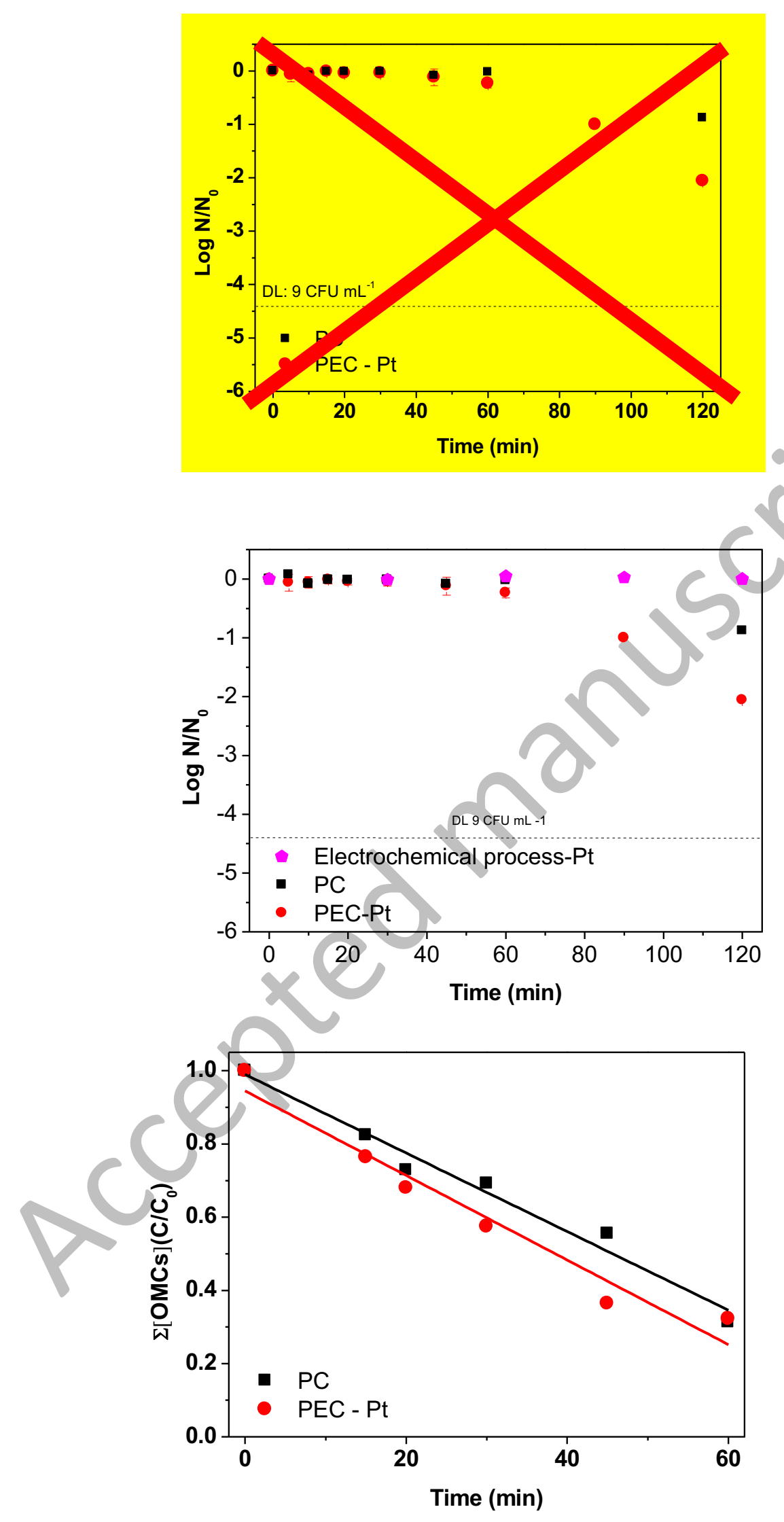

a)

b)

Figure 4. a) E. coli inactivation and b) $\Sigma$ OMCs concentration during photocatalysis (PC), EAP with Pt cathode (PEC-Pt) in surface water. 

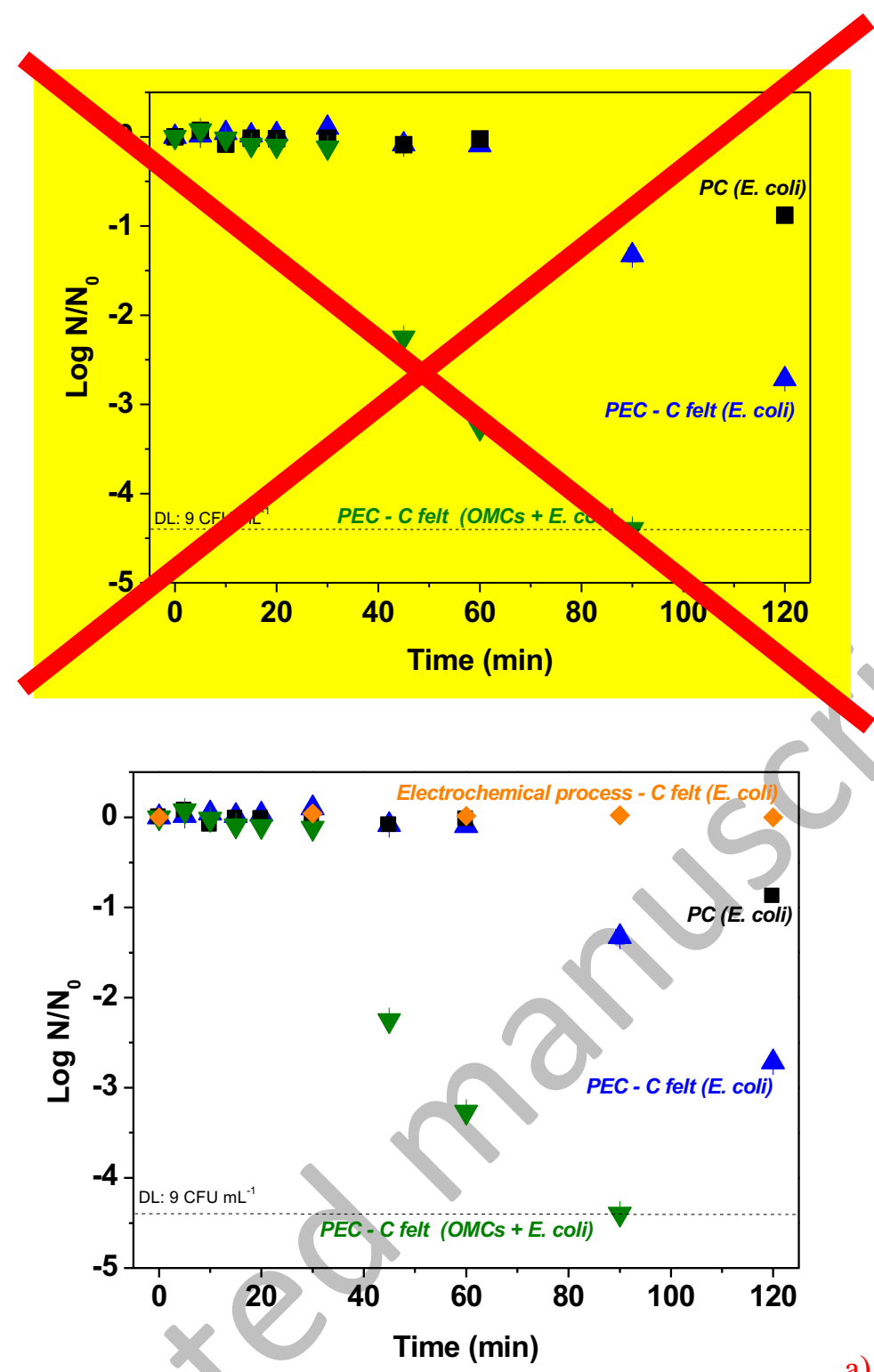

a)

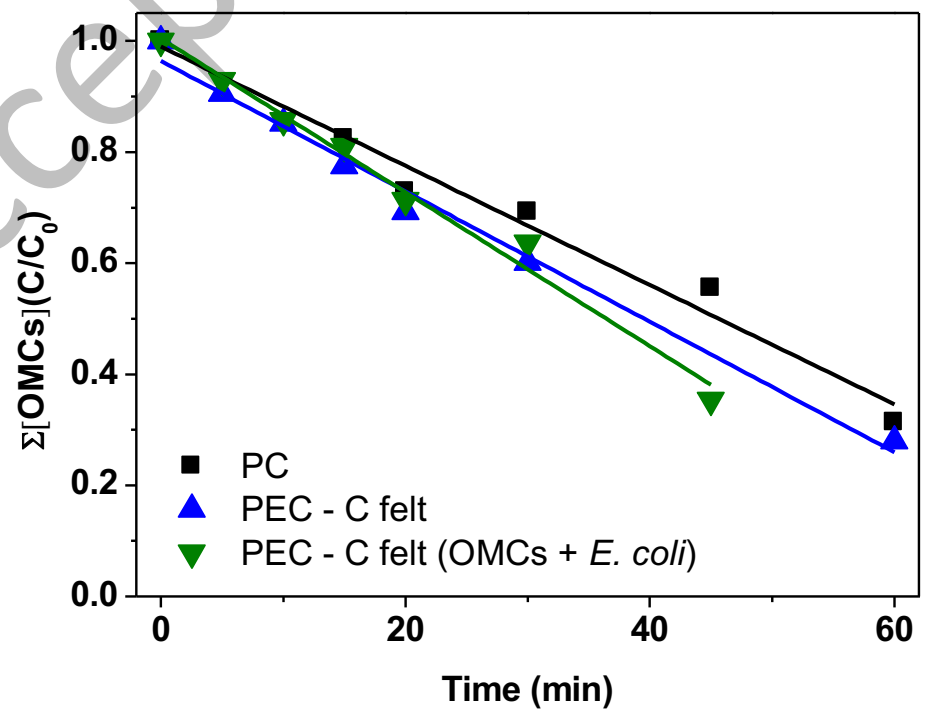

b) 
Figure 5. a) E. coli inactivation and b) OMCs degradation profiles obtained by photocatalysis (PC), photoelectrocatalysis with carbon-felt cathode (PEC-C felt) in surface water.

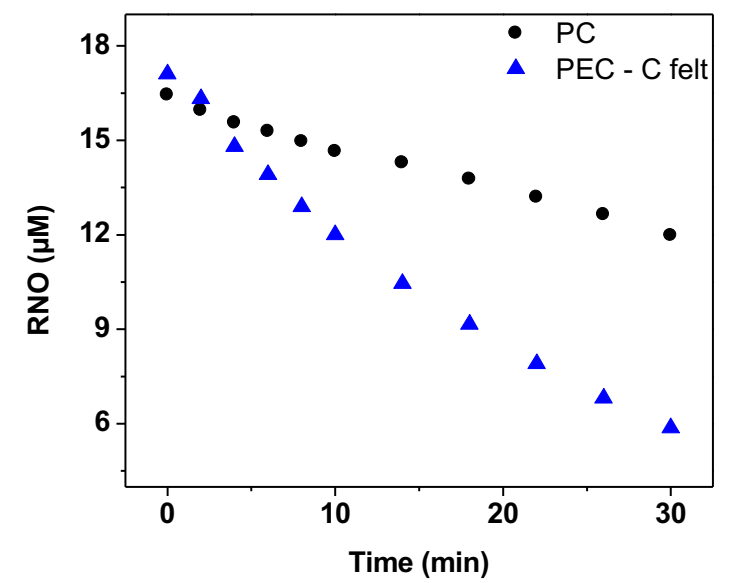

a)

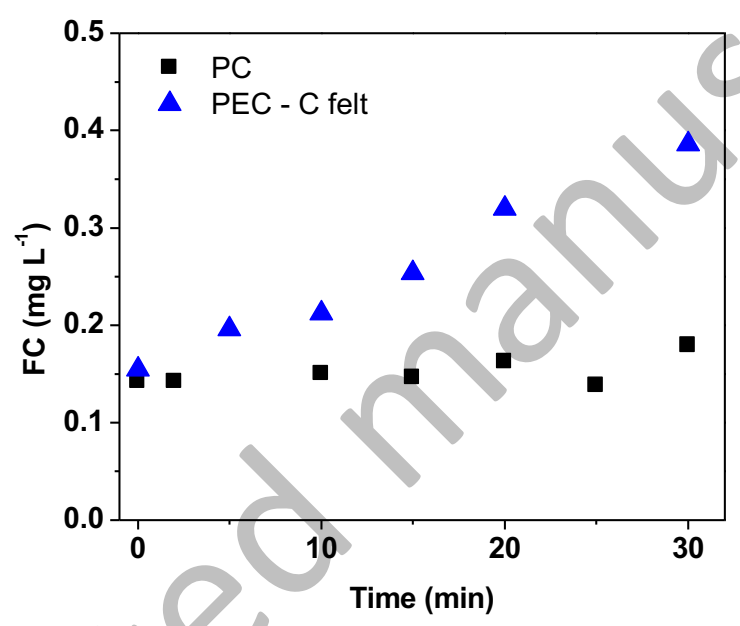

b)

Figure 6. Generation of a) RNO bleaching and b) FC during PC and EAP in a PEC-C felt cathode. 


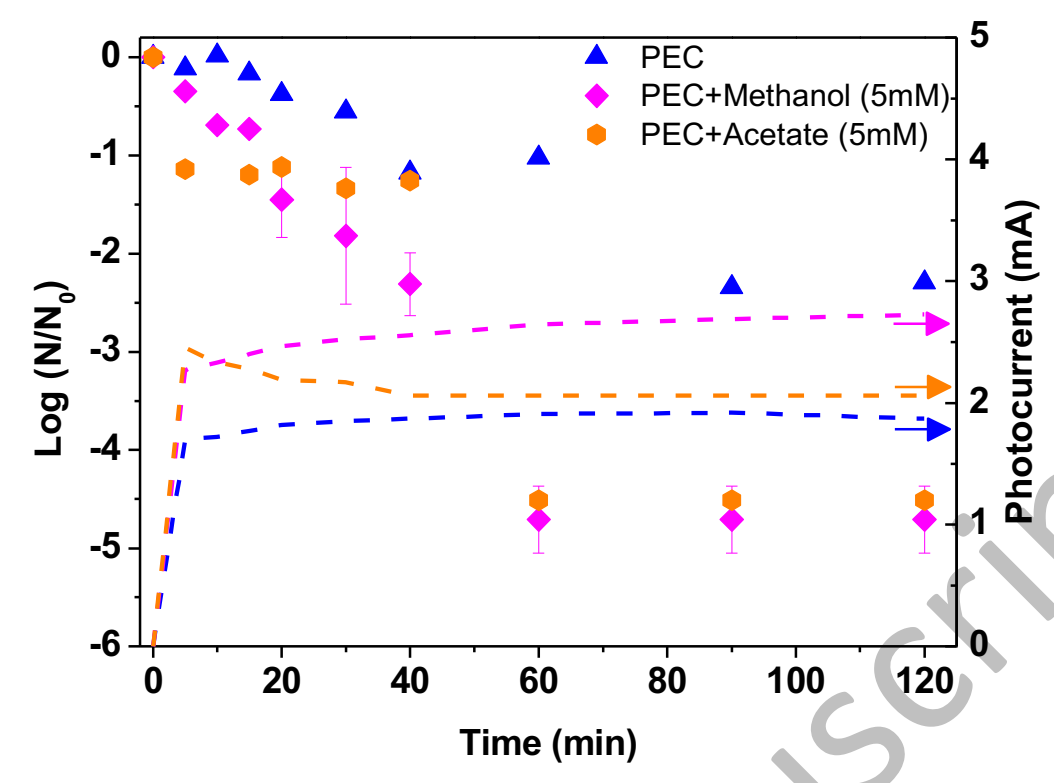

Figure 7. E. coli inactivation profile for PEC with C-felt cathode with methanol and acetate as hole acceptors. 


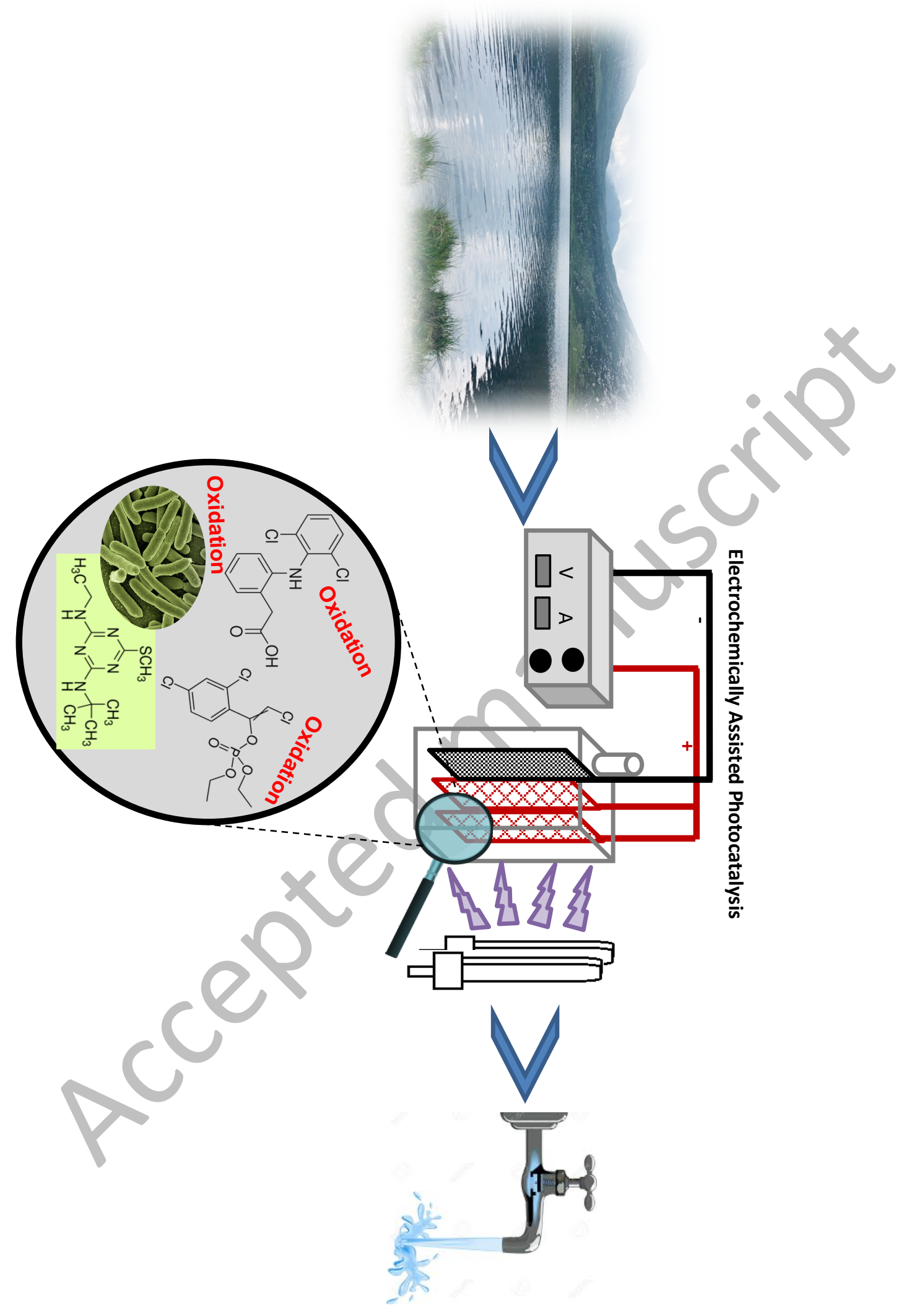


Title: Electrochemically Assisted Photocatalysis for the Simultaneous Degradation of Organic Micro-Contaminants and Inactivation of Microorganisms in Water

Authors: I. Salmerón ${ }^{\mathrm{a}}$, P. K. Sharma ${ }^{\mathrm{b}}$, M.I. Polo-López ${ }^{\mathrm{a}}$, A. Tolosana ${ }^{\mathrm{b}}$, I. Oller ${ }^{\mathrm{a}}$, J.A. Byrne ${ }^{\mathrm{b}}$, P. Fernández-Ibañez ${ }^{\mathrm{b}}$

aPlataforma Solar de Almería-CIEMAT. Ctra Senés km 4, 04200 Tabernas (Almería), Spain.

${ }^{b}$ Nanotechnology and Integrated BioEngineering Centre, School of Engineering, Ulster University, Northern Ireland, BT37 0QB, United Kingdom

\section{Supplementary information}


Table SI-1. Physic-chemical characterization of surface water used in this study.

\begin{tabular}{ll}
\hline Sodium & $14.9 \mathrm{mg} \mathrm{L}^{-1}$ \\
Ammonium & $0.2 \mathrm{mg} \mathrm{L}^{-1}$ \\
Magnesium & $13.5 \mathrm{mg} \mathrm{L}^{-1}$ \\
Calcium & $50.5 \mathrm{mg} \mathrm{L}^{-1}$ \\
Potassium & $1.2 \mathrm{mg} \mathrm{L}^{-1}$ \\
Chloride & $18.4 \mathrm{mg} \mathrm{L}^{-1}$ \\
Nitrite & $0.1 \mathrm{mg} \mathrm{L}^{-1}$ \\
Nitrate & $2.8 \mathrm{mg} \mathrm{L}^{-1}$ \\
Phosphate & $1.3 \mathrm{mg} \mathrm{L}^{-1}$ \\
Sulphate & $110.9 \mathrm{mg} \mathrm{L}^{-1}$ \\
pH & 7.4 \\
Conductivity & $697 \mu \mathrm{S} \mathrm{cm}^{-1}$ \\
Turbidity & $0.1 \mathrm{NTU}^{-1}$ \\
DOC & $6.9 \mathrm{mg} \mathrm{L}^{-1}$ \\
\hline
\end{tabular}

Table SI-2. Retention time, LOD, LOQ and maximum absorption of each OMC used in this study.

\begin{tabular}{|c|c|c|c|c|}
\hline OMCs & $\begin{array}{l}\text { Retention time } \\
\text { (min) }\end{array}$ & $\begin{array}{c}\mathrm{LOQ} \\
\left(\mu \mathrm{g} \mathrm{L}^{-1}\right)\end{array}$ & $\begin{array}{c}\text { LOD } \\
\left(\mu g \mathrm{~L}^{-1}\right)\end{array}$ & $\begin{array}{c}\text { Maximum } \\
\text { absorption }(\lambda)\end{array}$ \\
\hline TBT & 10.6 & 130 & 10 & $230 \mathrm{~nm}$ \\
\hline CVP & 13.5 & 170 & 40 & $240 \mathrm{~nm}$ \\
\hline DCF & 12.7 & 40 & 40 & $285 \mathrm{~nm}$ \\
\hline
\end{tabular}




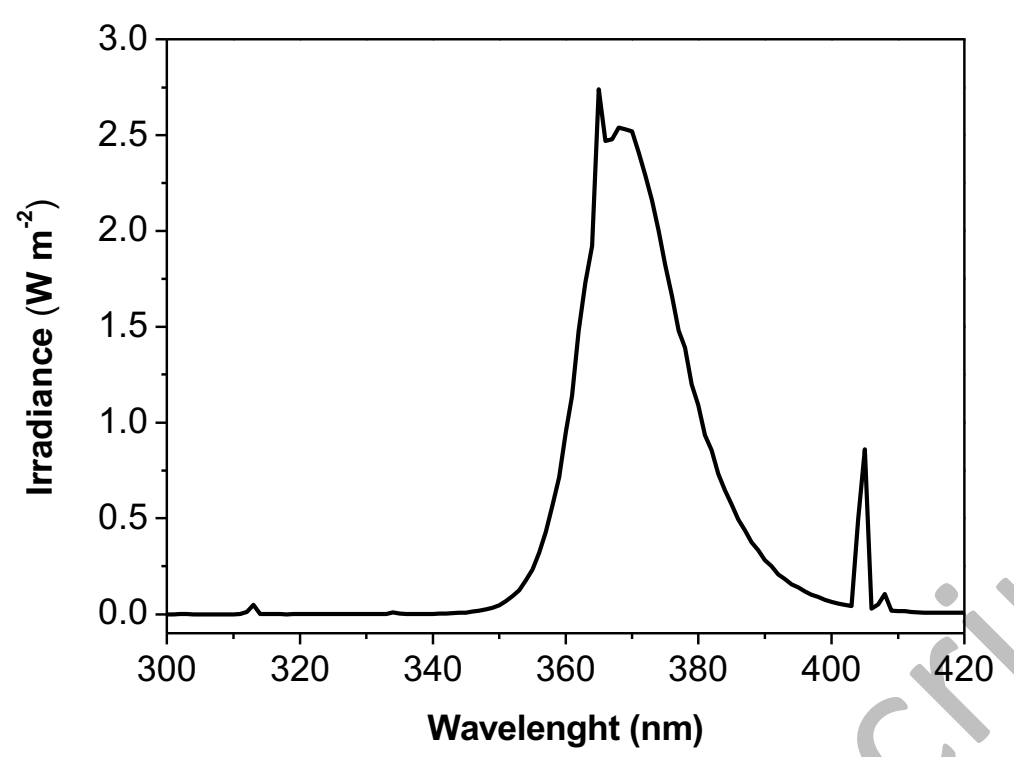

Figure SI-1. Irradiation profile of the $9 \mathrm{~W}$ UVA blacklight lamps used to illuminate the $\mathrm{TiO}_{2}-\mathrm{NTs}$ photoanodes.

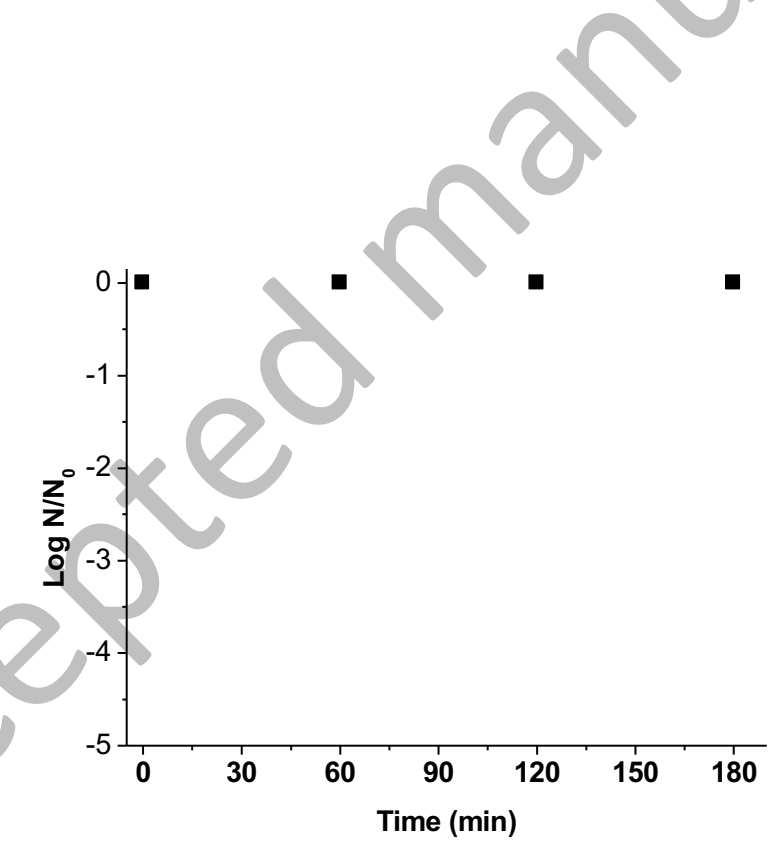

Figure SI-2. Profile of E. coli concentration detected along $3 \mathrm{~h}$ in the presence of $500 \mu \mathrm{gL}^{-1}$ of each $\mathrm{OMC}$ in the dark. 


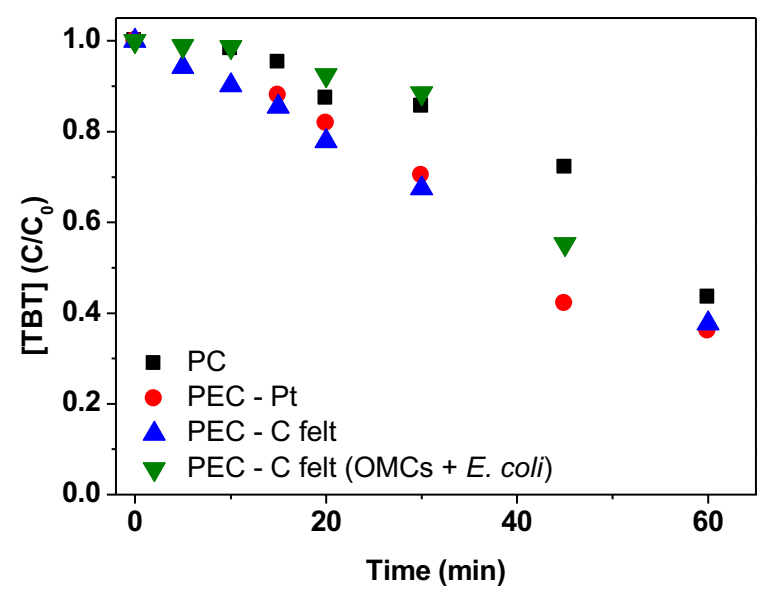

a)

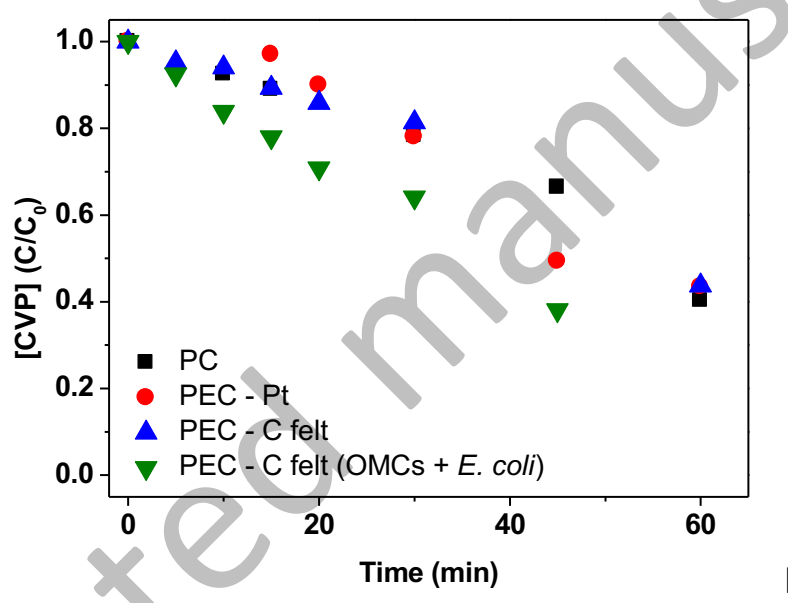

b)

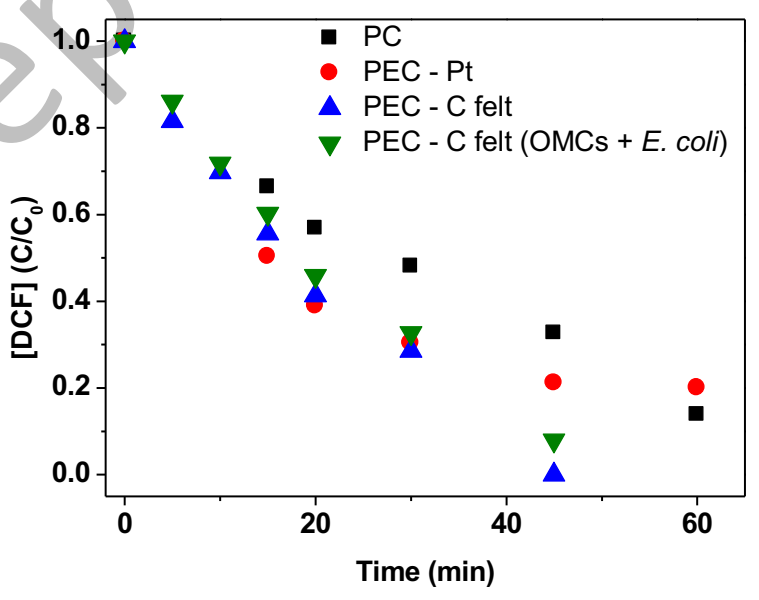

c)

Figure SI-3. Degradation profile of each OMCs during the development of the different tests, a) TBT, b) CVP and c) DCF 